University of Louisville

ThinkIR: The University of Louisville's Institutional Repository

1939

\title{
A study of student participation in school government and activities in Louisville Junior High School and Louisville Girls High School.
}

Margaret S. Bennett

University of Louisville

Follow this and additional works at: https://ir.library.louisville.edu/etd

Part of the Elementary and Middle and Secondary Education Administration Commons

\section{Recommended Citation}

Bennett, Margaret S., "A study of student participation in school government and activities in Louisville Junior High School and Louisville Girls High School." (1939). Electronic Theses and Dissertations. Paper 1664.

https://doi.org/10.18297/etd/1664

This Master's Thesis is brought to you for free and open access by ThinkIR: The University of Louisville's Institutional Repository. It has been accepted for inclusion in Electronic Theses and Dissertations by an authorized administrator of ThinkIR: The University of Louisville's Institutional Repository. This title appears here courtesy of the author, who has retained all other copyrights. For more information, please contact thinkir@louisville.edu. 
UNIVERSTTY OF LOUISVILLE

\author{
A STUDY OF STUDENT PART ICIPATION IN \\ SCHOOL GOVERNMENT AND ACTIVITIES \\ IN LOUISVILLE JUNIOR HIGH SCHOOL AND \\ LOUISVILLE GIRLS HIGH SCHOOL
}

\author{
A Dissertation \\ Submitted to the Faculty \\ of the Graduate School of the University of Loulsville \\ In Partial Fulfillment of the \\ Requirements of the Degree \\ of Master of Arts \\ Department of Education \\ By \\ Margaret $\mathrm{s}$. Bennett
}

1939 
Name of Student: Margaret $S$. Bennett

Title of Thesis: A Study of Student Participation in School Government and Activities in Loulsville Junfor High School and Louisville Girls High School

Name of Director:

Approved by a reading | dommittee composed of the following members:

Representative of the English Department:

Date: gume 2,1939 


\section{ACKNOWLEDGMENT}

The writer wishes to take this opportunity of thanking the various persons who so generously assisted in making this thesis posible. Especially does she thank President R. A. Kent, Dean J. J. Oppenhelmer, Dean Hilda Threlkeld, Dr. Mary E. Burton, and Dr. W. T. Rowland for their helpful criticisms. Among others her sincere appreciation is due to Ir. Samuel B. Tinsley, Miss Anna Voegtle, and members of the Halleck Hall faculty together with the students of the school who contributed with the written records, criticisms, questionnaires, and detailed information without which this thesis would not have been possible. To them the writer wishes to acknowledge her deep appreciation. 
A STUDY OF STUDENT PARTICIPATION

IN SCHOOL GOVERNMENT AND ACTIVIPIES

IN LOUISVILLE JUNIOR HIGH SCHOOL AND LOUISVIULE GIRLS HIGH SCHOOL 
TABLE OF CONTENTS 
CONTENTS

Page

Chapter I. Introduction

A. The Purpose of the Study 1

B. Material and Procedure 2

C. Iimitations of the Study 4

Chapter II. General Background of the Student

Farticipation Movement

A. Summary of the History of Student Government

B. Basic Theories Underlying Student Participation

1. Philosophical and Theoretical Bases

2. Fsychological Basis 14

3. Important Research Studies on Value of Student Participation 17

C. Objectives of Student Participation According to Contemporary Authorities

D. Characteristics of Good Programs 24

Chapter III. The Development and Organization of Halleck Hall Junior and Senior AllStudent Association

A. The Halleck Hall Organization 28

B. Historical Development of All Student Government

C..Present Administration and Orgenization of Stuỏent Government.

1. Organization of the AllStucient Association at Halleck Hall 4

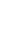




\section{CONPENTS (con)}

Chapter V. Conclusions and Sumnary

Page

A. Character of Halleck Hall

Development in Comparison with

General Movement

84

B. Present Status of the Program 86

C. Suggestions for Future Work 88

Appendix

92

Bibliography

112 
CHAPTER I

INT RODUCT ION 
CHAPTER I. INTRODUCTION

A. The Purpose of the Study

Some twenty years ago American schools were face to face with a new and challenging democratic problem: that of recognizing the right of the students to have some share in the responsibilities of carrying out the school program. Secondary schools all over the country are each year becoming more and more convinced of the 1dea of some form of comoperation in which the faculty and the students work in harmony for the best interests of the school.

It is the purpose of this study, therefore, to consider that phase of student activity--student participation in school govermment--as found working successfully in the Halleck Hall Junlor and Sentor High School at Louisvilie, Kentucky. The writer's aim, first of all, is to present an accurate, comprehensive overview of the evolution, form, and functions of the student participation in school government program now in operation at Halleck Hall. Other material has been introduced only as It sheds light upon these aspects of the study. The historical development has been strongly emphasized, for the writer has been interested in tracing the continu-

1 Made up of the Louisville Junior High School and the Loulsville Girls' High School. 
ous growth of the movement since its local inception at the Louisville Girls' High School in 1917. The writer has also been especially interested in the possibllities of student participation in school government as training in living in a democratic society and has centered much of her thinking upon the question of whether the All Student Association as organized at Halleck Hall may be a specific means of causing students to discharge more effectively their present and future scholastic and civic responsibilities.

\section{B. Material and Procedure}

In tracing the gradual growth of student participation in school government at Halleck $\mathrm{Hall}^{1}$, the written records of the Loulsville Girls' High School Student Council, compiled over a perlod of Its twenty-one years of organization, are a valuable source. The records of the four years of organization of the junior high school student council at Halleck Hall are also available and were, of course, of primary importance to the study. The writer, having been a member of the junior faculty since its organization at

1 In September, 1934, the Halleck Hall Junior and Senior High School was organized by the consolidation of the Loulsville Girlg' High School and the Ioulsville Junior High School, made up of the seventh, eighth, and ninth grades of the various feeder schools within a given radius of Halleck Hall.

2 The written records are kept at Halleck Hall. 
Halleck Hall, has had ample opportunity to observe the All Student Assoclation (the collective name applied to both councils) actually at work and, also has had an opportunity to get the general day to day reaction of the faculty and students toward this type of student participation in school government.

In addition to these last very personal and subjective sources, the writer has had interviews and less formal conversations with the Halleck Hall administrators and various faculty members about the movement. A check list based on advantages given by various writers on the subject was submitted to all the faculty. A simpler check list ${ }^{I}$ was submitted to the senfor and junfor students. The answers have been carefully studied and are extensively quoted in Chapter IV, dealing with the evaluation of the set-up.

The writer has read widely in the ilterature of the movement in an effort to gain as complete a background as possible. The bibliography lists the materlal she has found most helpful.

The historical background of the movement of student participation in school government in the United States

I The questions were asked orally by the writer during convenient study periods. Answers were submitted in writing, unsigned, of course. 
and its theoretical and psychological bases will be discussed briefly, and important recent studies dealing with the topic will be reviewed, with an idea of bringing the contributions and opinions of the best thinking and practice of well-known educators to bear upon the consideration of the problem. Attention will then be directed to the Halleck Hall situation in its various aspects: history, organization, function, and value. The writer hopes, from time to time, to draw some definite conclusions and make some recommendations. She feels that this plan of student participation is a valuable means of training students in junior cltizenship, and one which school administrators may make use of in putting into effect a similar program in their schools. Finaliy, a summary and suggestions for improvement of the All Student Association at Halleck Hall will be made.

\section{Limitations of the Study}

The study covers the perlod 1917-1938, from the origin of the movement at Loulsville Girls' High School to the current year. The movement at Loulsville Girls' High School and its continuation at Halleck Hall are the only situations considered. Student participation in school government has been rather widely adopted in the Loulsville public school system, but the writer 
preferred limiting herself to the situation with which she is best acquainted to attempting a comparative study. As noted before, the historical aspect of the local movement has been chiefly stressed. Much of the evaluating material presented mast, of necessity, have a purely subjective basis; in all instances, however, the writer has attempted to deal fairly with particular defects. 
CHAPTER II

GENERAL BACKGROUND OF THE STUDENT PART ICIPATION MOVEMENT 
CHAPTER II

GENERAL BACKGROUND OF THE STUDENT PART ICIPATION MOVEMENT

A. Summary of the History of Student Government

Student participation in school government did not receive mach favorable recognition in the United States until within the last twenty-one years. While the idea Itself cannot, strictly speaking, be called modern, its full- possibilities were not understood or incorporated into actual working practices by many educators for some time after a few early ploneers had blazed the trall for its future usefulness as a means of citizenship training.

The 1dea of pupil participation in government is not new. Part of the reason for the pupils' growth, well-being and happiness in Vittorino da Feltre's "Pleasant House," Ia Casa Giocosa, could be found in a kind of mixture of democracy and paternal1sm, that eluded the pup1ls to part1cipate in governing themselves. This school, this "House of Delight" at Mantua (1428-46) could develop such happy, democratic relations because of the genius of the teacher and the intelifgent understanding of his chief patron, the Prince of Mantua, and more especially of his wife, the Marchioness Paola. The swift intuitions of a genius toward right methods required then, as now, that the patrons of a school have at least some appreciation of the work of the school.

In studying colonial schools in America, one does not carry away the idea that a typical one was a "house of delight," yet there are many recorded instances of pup1l participation in government. Take, for example, this 1llustration from the Students' Gazette, number 7, pages 1-2, July 23, 1777, of the Penn Cherter School, Philadelphia.

To a considerate mind how pleasing it must be to take a view of the laudable spirit of the boys of this school. Actuated by a noble principle and desirous to prevent the 111 effects of internal broils they have established a constitution founded on their own authority. By virtue of this constitution an assembly is regularly chosen every month and empowered to make such laws as they shall 
think necessary or useful... Since this valuable institution has been adopted the absurd practices of fighting and calling names have visibly declined among the boys who now carry themselves toward one another with a delightful and polite behavior...The members of the assembly to qualify themselves for the office to which they are intrusted must apply themselves with great industry to the study of the law and rules in which some of them are so proficient as to be able to draw ap a bill in language that does honor to themselves and the school they represent. This will certainly be of great advantage to them hereafter, for when they are arrived at manhood and entered upon the busy scenes of Iife they will be useful members of society and qualified to serve their country in distinguished posts of honor and profit.

This quotation just presented must sound strangely moderm to those who insist that it is only in the present time, with the emphasis on education and training in citizenship, that there is any real recognition of the worth of pupil participation in government.

Pupil participation in government has been confused with self-government. In the revival of interest in the relation of pupils to school government in the last quarter of the nineteenth century and the first decade of the twentieth, one has but to read the educational literature of the period to see that the emphasis was on so-called self-government. Self-government was in the air ${ }^{1}$.

About forty years ago a few progressive schools in this country began to delegate a considerable responsibility to pupils for their conduct. Such pioneers as Dr. Bernard Cronson and Mr. Wilson Gill belleved that discipline and government of the school served as a valuable adjunct to teaching good citizensh1p" ${ }^{2}$. Mr. Gill, in 1891, had organized an elaborate scheme of pupil self-government which he called the Patriotic League of America.

Probably one of the earliest, best known, most successful

1 E. K. Fretwell, Extra-Curricular Activities in Secondary Schools, 1931, pp. 89-90.

2 Bernard Cronson, Pup1l Self-Government, 1907, p. 45. 
experiments in student self-government was inaugurated by Mr. William R. George, when, in the summer of 1895, he founded his Junior Republic at Freeville, New York ${ }^{I}$. Mr. George gave over largely, to the students the management of his boys' school. His experiment was so successful that it soon ceased to be an experiment and recelved much favorable comment; in fact, several other republics were founded, and today there is still functioning a National Association of Junior Republics.

Another one of the early ploneers in the movement was R. R. Smith, who, at the beginning of the twentieth century, was very successful in carrying out three experiments in student government in three Indians schools. 2

Between 1910 and 1920 the movement spread very rapidiy, and many schools were soon participating. For some it never passed the experimental stage and died out after several years, often in conditions approaching chaos. The following selections are presented as typical instances of the inauguration of a program of student government at this period:

In the Senn High School (in Chicago), the system of student government, initiated by a principal fuily aware of the importance of civic enterprise for citizenship training, has

I See William R. George, The Junior Republic, Its History and Ideals, 1910.

2 R. R. Smith, "Three Experiments in Pup1l Self-Government," Education, 37:23-4 (December, 1916). 
grown up with the school... It came into form in 1917 with a desire of an usually alert freshman class to help the incoming freshmen to orlent themselves. From this it grew into a sophomore council. As the class was promoted, it carried on its civic spirit, until presentiy there were four councils. Meanwhile, the division rooms, groups of approximately forty students each, had organized, elected officers, and were holding one regular club meeting a week at which room affairs, problems of high school courses, vocations, colleges, etc., were discussed. The candidates, nominated by petitions signed by their class mates, made speeches at election assemblies and were voted for by secret ballot. Assemblies by years in Senn $\mathrm{Hall}$ were falling into a regular schedule. Then a need appeared for some general group which should be able to view more completely the work of the whole school. In 1921, representatives of the four councils planned a new body, since called the All School Council, made up of the presidents of the classes, who are always elected from the "A" sections of the classes, and representatives from the " $B$ " sections. I

The school constitution (of the Ben Blewett Junior High School, St. Louis) prescribes the higher order of government, each room electing two congressmen, a boy and a girl, to the student congress, there being one congress for each grade under the supervision of the faculty grade administrator. Congress meets at the call of the administrator and considers matters pertaining to student government, student interest, or other needs of the school. The congressmen report to their advisory groups such action as may be taken.

The School Cabinet is a smaller body made up of the princip al, assistant principal, the three grade administrators, one teach from each grade chosen by the principal, one boy and one girl elected by each group grade congress and student delegates from the school paper, Junior Iife, from the corridor officers, from the Blewett " $B$ " Councll (an honor group), and from certain athletic, civic and music clubs.

In January, 1917, an experiment in student government was begun by the senior class of Central High School at Evansville, Indiana. At first, about thirty-six students were involved, and the experiment continued on this small scale for about three years, gathering momentum slowly, but rather surely,

1 Margaret M. Sleezer, "Student Citizenship at the Senn High School," The School Review, 32:508-52 (September, 1924).

2 R. I. Iyman, "The Ben Blewett Junior High School of St. Louls", The School Review, 28:26-40; $97-111$ (January:Febmary, 1920) 
until in March, 1920, the plan, much extended in scope, was taken over by more than one thousand boys and girls of the tenth, eleventh, and twelfth grades. All things did not go well under student government, but by 1922 it had broadened and established itself so thoroughly that teachers were no longer required to do police duty in halls, corridors, lunch rooms, assemblies, or nay part of the building, and the principal felt fairiy safe in announcing that any one of the two thousand students enrolled who felt that he had not received just treatment from the principal could appeal the case to the "Court of Prefects", the highest authority in student government, and that the principal would abide by the decision of the Prefects. 1

The experiments cited above were experiments in selfgovermment. A change in thinking gradually came about, and the expression "pup1l participation in government" evolved as the result of a more simple and effective means of pupil co-operation in school government. Though the change is a significant one, the distinction between the two phases has frequently been overlooked or ignored. J. A. Shelden.

writes: "During these years of experimentation a number of changes or trends has been noticeable. The tendency, for example, to delegate to pupils the responsibility for discipline analogous to those of police and courts has for more than a decade been giving way to the practice of charging pupils with managerial rather than detective and punitive functions." 2 Gradually, therefore, a new conception of

I John C. Chewning, "Student Self-Government," National Education Association: Addresses and Proceedings, V01. 63, 1985, pp. 737-42.

2 James A. Shelden, "Pupil Participation in School Control in High Schools of Iowa," The School Review, 43:189-97, (March, 1935) 
discipline for secondary schools began to take the place of the traditional autocratic idea that Roberts and Draper speak about, according to which "the principal was on hall duty, teachers stood at their doors, Jams-faced, looking both ways, and janitors held their posts of observation when students passed through the halls." I

Olivia Pound, in 1918 reported on the investigations of pupil activities in seventy-five representative schools. In her report she noted "the wide difference of opinion among school authorities in regard to the advisability of student particlpation in the management of the school. Twenty-five administrators seemed to have no definite opinion on the subject. Others seemed to confuse the project with student self government or were opposed to it altogether, as the following comments will show. 'Students should study and recite.' 'Teachers should teach and supervise.' 'Students should not have a direct voice in governing their fellow students.' 'A school must be a "benevolent despotism." "There should be no student participation absolutely, except as school spirit and respect for proper authority may assist. $" 12$

1 Alexander C. Roberts and Edgar M. Draper, Extra-Class and 2 Intra-Mural Activitios in High Schools, 1928, p. 49 Olivia Pound, "Social Program for the High School," The School Reviez, 26:166-167, (March, 1918). 
B. Basic Theorles Underlying Student Participation

1. Philosophical and Theoretical Bases. Certain definite changes in the educational theory and practice concerning high school have found their way into our colleges and teacher-training institutions and through them have influenced the teaching profession. Fifty years ago the secondary school was conceived to be only a preparation for college and professional training; therefore, a most rigorous discipline was thought necessary in order to reach that goal. The school then passed through a transition period when it was thought of not as a preparation for college but as a preparation for life. At the beginning of the twentieth century, educational philosophers under the leadership of Professor John Dewey, startled the educational world by bringing forth a new education theory for the school: It was neither a preparation for college nor a preparation for life, but life itself. With such a new theory of education, a determination to make that life rich, full, and adequate became the central idea of the high school program. No more was the old type of school able to meet the challenge of the new. Professor Dewey wrote in 1900: "A society" (and the school to him was one form of society) "Is a number of people held together because they are working along common lines, in a common spirit, and with reference to common aims." I

\footnotetext{
John Dewey, School and Soclety, 1900, pp. 11-12.
} 
Another philosopher who has been a powerful force in formulating a new concept of the responsibility of the school to the Individual is William Heard Kilpatrick. Kilpatrick's Education for a Changing Civilization was one of the books that blazed the trail to new avenues of thought and action. "Change, change, on every hand is seen," wrote Kilpatrick. ${ }^{1}$ The school must meet this challenge. That the school must allow for "actual experiencing in the social situation" ${ }^{2}$ was the moving, dynamic force of Kilpatrick's philosophy. He once wrote: "Education must study consciousIy to enrich life. Any proposed experience to be acceptable must reach into new territory so as to promise worthwhile learning and growing. Any proposed experience must make for the rounded life we need." 3 A recent commentator on the movement sums up its basic theory thus:

The theory back of this education is to develop the ability to recognize new problems, the habit of thinking in terms of social welfare, including a realization of individual profit in well-being as well as the personal menace of social and economic maladjustment, and skill in the cooperative activities through which a democratic social order must function. What is perhaps of greater importance is that the student participation furnishes a genuine social situation with constantly changing problems.

I W. H. Kilpatrick, Education for a Changing Civilization, $1931, \mathrm{p} .81$. 2 ibid., p. 81 .

3 W. H. Kilpatrick, Our Educational Task, 1930, p. 107. 4 William D. Lewis, "The School as a Democratic Institution," Fourteenth Yearbook, The National Elementary Principals Bulletin of the Department of Elementary School Principals, pp. $415-1 \%$. 
If it accepts such a theory, the school must become "the nucleus, the training center, or, in other words, the laboratory of democracy", for the philosophy of democracy in education implies that the school will provide an opportunity for the students to make their school life a replica of efficient citizenship. This practice will make for a finer and higher type of "citizen of tomorrow" because he has had experience in governing himself in a democracy.

To meet this new challenge in education, therefore, the schools are to be more democratic in their management, thus giving the pupils an opportunity to practice socialcivic virtues. For this reason the better high schools favor student participation in their government, and thus utilize the school situation to mold character through actual practice.

2. Psychological Basis. Student participation in school government provides a general learning situation in which certain specifically personal traits may be developed, such as initiative, responsibility, self-reliance, selfcontrol and leadership. Thorndike gives us three laws of learning, namely, readiness, exercise and effect. These laws have no value when developed by themselves but may be applied as adjuncts to a process of learning as directed

I

I. K. Juergensmever, "Students Run This School", School Executive Magazine, 64:314 (June, 1935) 
toward a given goal such as training students to develop the traits mentioned above.

Student council work provides opportunity for pupils to become enthusiastic and genuinely interested in certain activities. Thorndike's law of readiness implies that the more a person is interested in a given learning situation the more he will learn. The enthusiastic student councilor will have a definite purpose of his own, such as wanting to "put across" a safety innovation in the passage of classes through the crowded halls, create an interest in a proposed track meet or some other worthwhile activity for the good of his group. "This purpose he must make clear to his associates through explanation if he is to get it accepted by his group. If it is his purpose, it has in it a drive for him that makes for action. Psychologically, this is the law of readiness wherein to act is satisfying and not to act is annoying."

Granted that the councilor has made clear to his fellow students his purpose, his next step is to get it accepted by his group. Psychologically, the law of exercise here comes into play for the councilor has an opportunity to acquire practice with a real situation. "He must present his case, speak clearly and definitely, to an exacting audience; he has to work in accordance with orderly procedure; he must recognize the chairman,

1

Elbert K. Fretwell, Extra-Curricular Activities in Secondary Schools, 1931, p.102. 
present his motion, struggle with the fickleness of public opinion, get a working comittee appointed. The purpose that he has may make him strive for exactness, a completeness in result." ${ }^{I}$ During the course of his efforts the councilor has had opportunity to exercise such traits as initiative, self-reliance, self-control and leadership. other situations may arise when the councilor may have to exercise his authority and responsibility. Through all this exercise of meeting given situations satisfactorily comes a sobering process which tends to stimulate him and gain for him confidence in his own powers. Certain principles of future action will be outgrowths of his "trial and error" method, until finally he will learn to meet each new situation intelligently. This practice or exercise of carrying out a definite purpose forms much of the drive in student particlpation in school government.

The councilor has attained his goal--the "putting across" of some worthwhile activity. With this comes an emotional satisfaction and pride in having his own opinions considered favorably by his group. Psychologically, this is the law of effect. Interest and enthusiasm are a natural outgrowth along with the emotional satisfaction. "In every-day life it is usually the emotions that give the drive to human endeavor. The high school boy or girl

I

Elbert K. Fretwell, op. cit., p $10 \%$ 
is guided largely by feeling. There is a healthy emotional satisfaction for the pupil to share in directing affairs in the homeroom, class or council; to have one's opinion courteously considered by one's associates and especially by the members of one's own group; to have the consciousness of being expected to do the right thing and to help others to do it; to be a part of an organized group that in the very nature of the situation demands one's best effort in creating, bullding, promoting through co-operative effort. Action and emotion are inseparably associated." ${ }^{1}$ It is a fact also that behavior which is practiced and which brings satisfaction to the learner will be learned.

It is well to consider the concomitant learning that goes hand in hand with the other learning processes just reviewed. Through the exercise of his initiative, responsibility, self-reliance, self-control and leadership, the student is developing gradually certain desirable attitudes. An attitude of enjoyment is developed, for students love to see things accomplished through their own efforts. They learn to work to-gether, and through this participation, class barriers are broken down, attitudes of social equality and fair play are developed, better understanding, better spirit and co-operation between students and faculty, interest in school work, school spirit and school pride are

$I$

Elbert K. Fretwell, op. cit., pp. 107-108. 
developed. Another attitude that may develop as an outcome of the learning process is that of "intelligent obedience to authority." ${ }^{1}$ Having had a hand in making certain laws he will be more intelligently obedient as he will understand the "why" of such laws. Also "the working out of the attitudes may establish desirable habits and ultimately result in a knowledge of how to work in situations requiring individual initiative and co-operative effort." ${ }^{2}$

We see, therefore, that student councils do have many underlying principles that make for the development of civic habits needed in a democracy and do frequently present situations that satisfy the conditions established by Thorndike under which learning takes place.

3. Important Research Studies on Value of Student Participation. C. F. Poole in his thesis on Student Participation in School Government says that "the attitudes revealed throughout the literature on the subject is that it is entirely worthwhile as an educational agency." ${ }^{3} \mathrm{He}$ further states, quoting in part from N. A. Jackson:

"Some of the strongest argurnents favoring self-government

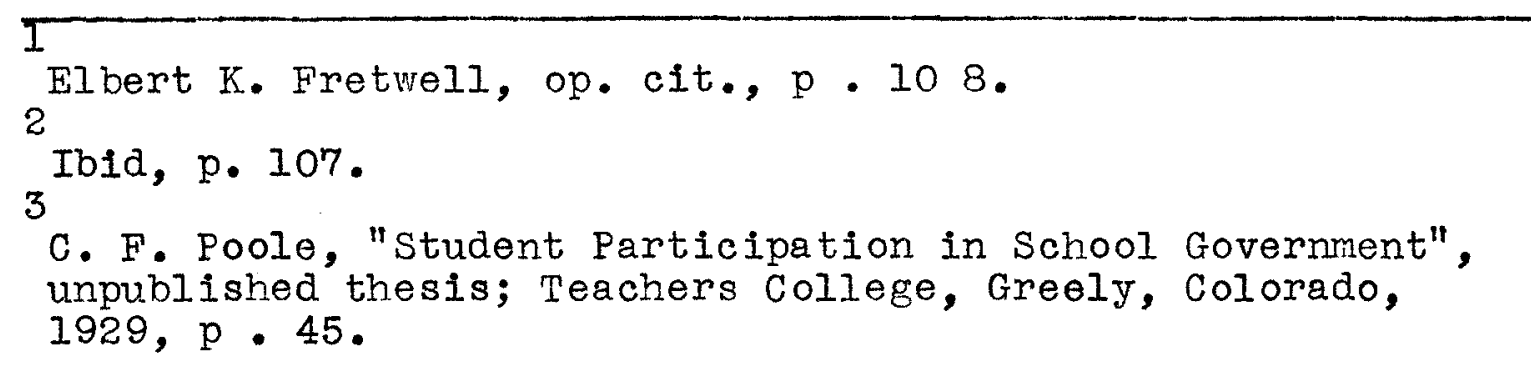


are, there is a training in leadership, in self-control, in the exercise of judgment and tact, and in the qualities that go to make up the perfect and useful citizen." II

Another advocate of student participation writes: "It is a factor in character development because it makes the pupils conscious of the problems of conduct and demands of them the exercise of initiative and choice rather than the dependence on the decision of others."2 Shelden says that in answer to the question, "What values do you see in student government?", seventeen percent of the school officials of Iowa believe that there is less disciplinary trouble because of the governmental organization. "School officials report that many careless, irresponsible children have developed into dependable leaders because of the responsibilities and duties given them through pupil organizations." 3 Earle Rugg, writing on the movement, concludes in part as follows: "Student participation in school government appears to be an important means of promoting worthy citizenship training in the schools."4

Fretwell summarizes the Ideal situation thus:

I C. F. Poole, partial quotation from N.A. Jackson, "Pupil Government in Secondary Schools," Education, 42:197-200, (December, 1921). Irving King, Social Aspects of Education, 1913, p. 49.

3 J. A. Shelden, loc. cit.

4 Earle U. Rugg, "Student Participation in School Government," "Twenty-fifth Yearbook, Nat. Soc. for the Study of Educ., Pt. II, pp. I39-140. 
The powers of the council of student's association should be derived from 211 the citizens of the school and within the scope of the charter granted by the principal. The pupils may become citizens with rights, duties, privileges, and obligations simply by entering the school. The participation in the home-room, in the class organization, and in the council and its committees is so important that every pup1l should be considered a citizen. The office of the president of the council should be the most honored position any pupil can attain in the school. The successful, organized participation of pupils in school government demands that the elected representatives shall not constitute themselves as an oligarchy and assume all power, but that the home-rooms and the various classes be organized so that opinion passes from the citizens to the council quite as free $\mathrm{y}$ as the directions of the council pass to the citizens. 1

The following table summarizes the most frequently mentioned advantages claimed for the student participation movement:

$$
\text { TABLE } I^{2}
$$

Some Practical Advantages Derived Through Student Partic1pation in School Government as Revealed by an Analysis by Poole of Sixty-five Articles Dealing with the Subject

\begin{tabular}{lll}
\hline Rank & \multicolumn{3}{c}{ Advantages } & Frequency \\
\hline 1. & $\begin{array}{l}\text { It teaches principles and methods of } \\
\text { government such as students need to } \\
\text { know in later life. }\end{array}$ & 38 \\
\hline & $\begin{array}{l}\text { It trains in leadership, in self- } \\
\text { reliance, and in self-control. }\end{array}$ & 26 \\
\hline & $\begin{array}{l}\text { It minimizes the need of constantIy } \\
\text { watching the behavior of students, }\end{array}$ & 20 \\
which is usually offensive to teachers \\
and students.
\end{tabular}

\footnotetext{
IE.K. Fretwell, op. cit., pp. 94-95.

2 c. F. Poole, op. cit., p. 34 .
} 
TABIE I (con)

\begin{tabular}{lll}
\hline Rank & \multicolumn{1}{c}{ Advantages } & Frequency \\
\hline 6.5 & $\begin{array}{l}\text { It trains In Independence of } \\
\text { thought and action. }\end{array}$ & 6 \\
\hline 8. & $\begin{array}{l}\text { It is a natural and probable } \\
\text { outlet for adolescent and instinc- }\end{array}$ & 4 \\
tive tendencies. & $\begin{array}{l}\text { It makes the pupil better able to } \\
\text { resist temptation in college and } \\
\text { business. }\end{array}$ \\
\hline
\end{tabular}

To summarize from the writer's reading and personal observation, the advantages that will accrue to any high school where pupil participation in the school government is functioning properly may be tabulated thus:

To the principal:

1. The need to concern himself with petty detalls of discipline is removed.

2. He can give his time as an educational administrator.

3. His resources of professional training $c a n$ be applied to larger problems of his school.

To the teachers:

1. They form a partnership with the students in matters of discipline.

2. They are free to give their best service to the classroom, unhampered by police duty.

3. The measure of their success does not depend upon disciplinary power.

To the school:

1. Better attitude toward the school is developed.

2. Permanent loyalty of students and parents toward the school is thus developed.

3. Attitude of principal, teachers, and students toward each other is changed to one of trust and understanding.

4. Democratic co-operation tends to raise the morale of the school.

To the students:

1. An opportunity to practice citizenship is given every student.

2. The responsibilities of the school citizen can be carried over into community life.

3. The students have the opportunity to grow in social adaptation.

4. Habit formation leading to good ethical character may be a natural outcome. 
To the students: (con)

5. The students are interested in obeying laws that they help to form.

To the comminity:

1. Closer relation between the home and comminity is established.

2. Students can make use in community affairs of practices and understandings gained through school participation.

C. Objectives of Student Participation According to Contemporary Authorities

Foster lists as immediate aims or objectives of student participation in school government: "(I) the teaching and practice of self-control, (2) self-reliance, (3) recognition and encouragement which student participation gives to initiative, ( 4 ) discovery and development of leadership, (6) establishment of citizenship."I

Student participation in school government should be a process and not a device. In the hands of an able educator it may be used as a "tool in furthering the cardinal

1 Chas. W. Foster, Extra-Curricular Activities in High Schools, 1925, pp. 59-107. 
principles of secondary education and not an end within itself." 1 our chief thought should be, will the student be developed in accordance with the se fundamental principles by participation in school government? If the "Invisible teacher" can have complete control but so remain in the background that the initiative seems to come from the pupil, best results are obtained, for the pupils are actual ly practicing citizenship by living it.

From Table II we note that such items as "To train for worthy citizenship through the development of cooperation, inftiative, and responsibility; to develop better understanding, better spirit, and co-operation between students and faculty; and to develop interest in school work, school spirlt, and school pride" rank as the three most frequently mentioned, in an analysis of fifty articles made by Poole. 


\section{TABIE II ${ }^{1}$}

Frequency and Rank of the Chief Objectives and Values or Claims for Student Participation in the Government of the School as Revealed by an Analysis by Poole of

Fifty Articles Dealing with the Topic

\begin{tabular}{|c|c|c|c|}
\hline Item & objectives & $\begin{array}{l}\text { Frequency } \\
\text { of Mention }\end{array}$ & Rank \\
\hline 1. & $\begin{array}{l}\text { To train for worthy citizen- } \\
\text { ship through the develop- } \\
\text { ment of co-operation, } \\
\text { initiative, and responsi- } \\
\text { bility. }\end{array}$ & 33 & 1 \\
\hline 2 & $\begin{array}{l}\text { To develop better under- } \\
\text { standing, better spirit } \\
\text { and co-operation between } \\
\text { students and faculty. }\end{array}$ & 13 & 2 \\
\hline 3. & $\begin{array}{l}\text { To develop interest In } \\
\text { school work, school spirit, } \\
\text { and school pride. }\end{array}$ & 9 & 3 \\
\hline 4. & $\begin{array}{l}\text { To develop lintelligent } \\
\text { leadership. }\end{array}$ & 6 & 4 \\
\hline 5. & To provide pupil expression. & $I$ & 5 \\
\hline
\end{tabular}

Ringsdahl reports that 179 schools listed such duties of their student government as these: to supervise extracurricular activities, 26; to control corridors and lunch rooms, 17; to control finances, 7; to control study halls, 5; to control discipline, 5; to control social affairs, 4; to give athletic and other awards, 3; to plan and conduct assemblies, 2; to care for bullding and property, 2.2

1 C. F. Poole, op. c1t., p. 34 .

2 N. R. Ringsdahl, "High School student Counc1ls," School Review, 36:329-37 (May, 1928). 
The following table presents the results of an investigation of the same question made by Roberts and Draper.

\section{TABIE III $^{1}$}

Number and Percentages of Schools in Which Certain Responsibilities are Borne by Student Government

\begin{tabular}{lcc}
\hline Responsibility & $\begin{array}{c}\text { Number of } \\
\text { Schools }\end{array}$ & Percentage \\
\hline Student organization & 139 & 33 \\
\hline Hall supervision & 24 & 6 \\
\hline Some discipline & 36 & 9 \\
\hline Assemblies & 24 & 6 \\
\hline Study Hall control & 11 & 3 \\
\hline Care of bulldings & 11 & 3 \\
\hline Some co-operation & 229 & 54 \\
\hline
\end{tabular}

D. Characteristics of Good Programs

In attempting to describe the characteristics of a good program of student participation in school government, one soon comes to feel that the particular form the participation takes is of secondary importance when compared to the necessity for the proper attitude on the part of the participants. Rugg, in the study quoted above, recognizes this tangible factor:

A school wishing to introduce student participation will do well to consider the following conclusions draw from a study of practices throughout the country for two decades.

1 A. A. Roberts and E. M. Draper, The High School Princlpal as Administrator, $1927, \mathrm{p} .217$. 
a. Student government should be introduced gradually.

b. The machinery for its administration should be simple.

c. The students themselves must desire in a genuine way to participate in the government of the school.

d. The faculty mist be sympathetic, patient, and willing in every way to make the movement a success. Student government is necessarily a co-operative matter.

e. The plan must provide for means by which all students are given opportunities to participate in the government of the school.1

Evidently the machinery of student govermment must be kept as simple as possible, for a simple government is not only more likely to be an efficlent one, it also provides better opportunity on the secondary level to study the typical functions of government. of equal importance, however, is the genuine desire of the students for the opportunity to participate. Nothing can be more disastrous than to have such a movement fostered upon the student body in the face of indifference or hostility. A corollary to this is the fifth point made by Rugg, for if a large part of the student body welcomes the chance to share in the school sovernment, but later finds that only a small percentage has the opportunity actively to participate, the majority will soon lose interest, and the minority will be forced to rely upon the authority of the teacher.

As to actual form of governmental set-up used, there are two important forms, both of which have proved satis-

I E. U. Rugg, op. cit., pp. 139-140. 
factory in actual use: the single-house and the two-house types of student council. The size of the councils and the electoral unit varies considerably. Ringsdahl's report on 179 schools states that "the size of the council varies from seven to thirty-four members with a median of twentytwo. The schools reporting were large schools with from 500 to 6000 pupils." It further notes: "Election of council members by classes, 38; by home-rooms, 31; at large, 12; as presidents of other organizations, 11; by home-rooms and class-rooms, 6; by organizations and classes, 6; in other combinations, 6 . Ordinarily by constitutional provision the upper classes elect more members to the council."

Similarly, there seems to be little agreement as to the functions to be delegated to the student councils. The following table was made by one investigator of the subject.

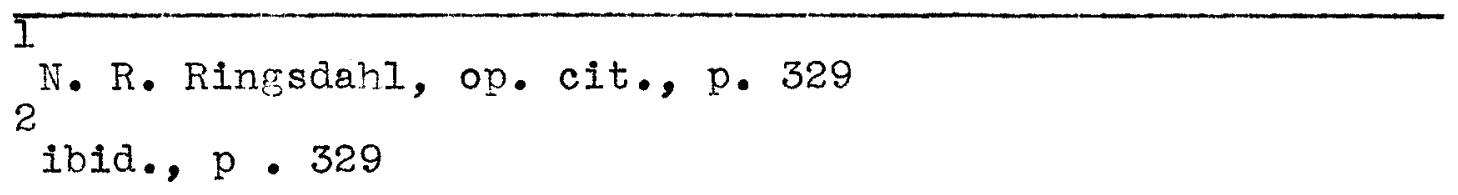


TABLE $I V^{I}$

Number of High Schools in Which Pupils Participate in the Control of Varlous Activities or Combination of Activities According to Voelker

\begin{tabular}{|c|c|c|}
\hline Activity & $\begin{array}{l}\text { Number of } \\
\text { High Schools }\end{array}$ & Percent \\
\hline Class-room (only) & 1 & 1 \\
\hline $\begin{array}{l}\text { Extra-curricular } \\
\text { activities } \\
\end{array}$ & 47 & 36 \\
\hline $\begin{array}{l}\text { Class-rooms and study } \\
\text { rooms }\end{array}$ & 1 & 1 \\
\hline $\begin{array}{l}\text { Study rooms and extra- } \\
\text { curricular activities }\end{array}$ & 5 & 4 \\
\hline $\begin{array}{l}\text { Corridors and extra- } \\
\text { curricular activities }\end{array}$ & 31 & 23 \\
\hline $\begin{array}{l}\text { Study rooms, examination } \\
\text { extra-curricular activ } \\
\text { ties }\end{array}$ & 12 & 9 \\
\hline $\begin{array}{l}\text { Corridors, extra-curricu } \\
\text { activities }\end{array}$ & $I$ & 1 \\
\hline $\begin{array}{l}\text { Class-rooms, study rooms } \\
\text { examinations, corridor } \\
\text { extra-curricular activ }\end{array}$ & Les & 3 \\
\hline
\end{tabular}

From the table above one notes that most high schools have more pupils engaging in extra-curricular activities. Thus we note that while student participation in school government is not, strictly speaking, a modem idea it was only favorably recognized in the United States within the last twenty-one years. Student participation is founded upon sound philosophical and psychological bases. The best educators indorse its practices as revealed throughout their literature dealing with the subject.

1 E. W. Voekker, "The Organization and Functions of Pupil opinion in High School Control," School Review, 34:654-67 (November, 1926) 


\section{CHAPTER III}

THE DEVELOPMENT AND ORGANIZATION OF HALLECK HALL JUNIOR AND SENIOR ALI STUDENT ASSOCIATION 


\section{CHAPTER III}

THE DEVELOPMENT AND ORGANIZATION OF HALLECK HALL

JUNIOR AND SENIOR ALI STUDENT? ASSOCIATION

A. The Halleck Hall Organization

Halleck Hall is two schools - a Junior and Senior High School, located at Second and Lee Streets, Louisville, Kentucky. The building, erected at a cost of more than a million dollars, is of modified Gothic architecture and built in the shape of an " $H$ ". There are seventy-five class-rooms and laboratories, and an auditorium seating 1200 with an equipped stage. Besides, there are three cafeterias, a gymnasium, administrative offices, a medical suite, and rest rooms. The annual enrollment is approximately 3000 , with a teaching staff of one hundred. The building, opened in september, 1934, was immediately overcrowded, since it was built for a capacity of 2600 . Three portables now relieve the congestion somewhat. The administrative staff consists of a principal, two assistant principals, one for the senior division and one for the junior division, and a dean of girls.

When the present school was opened, the senior department brought from the Loulsville Girls' High School a well organized student council. A short.time after the opening of the junior division, plans were under way for the organization of a junior council. Much of the success of the present All student Assoclation (name of the combined 
Senior and Junior Councils) is due to the "trial and error" of the twenty-one years of work of the senior student counc1l.

\section{B. Historical Development of All Student} Government

The All Student Association at Halleck Hall is, then, a heritage from the Louisville Girls' High School Student Council, which had its beginning in 1917. The present association is fortunate in having the accumulated written records of the principal activities of this group during the past twenty-two years. The writer, from time to time, will quote from these old records.

Quite a significant item about the establishment of this student government is the fact that the first idea of such student participation came from the girls themselves. In 1916, a group of girls attempted to write a constitution and under it organize a form of student government, but they were unsuccessful, as they had had no experience in this field of work. The attempt embodied an entirely new idea and probably received little encouragement from an uninformed and naturally disinterested faculty. However, the principal of the school, Mr. H. B. Moore, a man alive to the possibilities of student participation, decided to try out an experiment in student government during the following year. In February, 1917, he appointed a teacher, 
Miss Alice Parker, to aid the girls in their plans and subsequently to supervise the newly organized council. It is well to note that the faculty as well as the students desired this type of government. Therein lies one reason for its ultimate success.

The first council was in no sense democratic, as its members were appointed by the principal on advice of the faculty, not elected by the students. There was only a loose organization, and of course little progress was made. The council was faculty-muled, but the will to do was there, and a definite start had been made.

Little was accomplished at first because there was too large a group of girls to work with, and the rest of the school did not co-operate. The girls, however, helped to keep order in the halls and lunch rooms. These were the days when there were two recesses, as about 1900 girls were enrolled.

In 1919, at a regular meeting, a constitution was written and adopted. The object of the student council, as set forth in the constitution, was to secure the cooperation of the entire student body in matters of conduct and discipline, in order that the faculty might not have to deal with matters of this nature outside the classroom. Its aim was to foster a spirit of school loyalty and pride which would give the school a recognized standing among similar institutions of the country.

This constitution provided for the securing of members for the council as follows: Two nominations for members were made from each English class. Names were sent to the council, and the council elected the members so it could consist of three members each from English 8, 7, 6, 5, 4, classes, two English 3 's, one English 2. They had to be girls of good standing, both in character and grading. The faculty passed juagment on them after the decision of the council. The officers were elected by the council.

The duties of the members increased. They were on duty in the chapel, in the lunch room, halls, and gymnasium if dancing were going on at recess. A trial of student government in study halls was made, but it was not altogether 
successful becan se of the small number of regular student council girls and lack of co-operation. Student council girls helped in study halls, however. Class Day seating and ushering were managed by the student council. In 1921, the duties of the student council girls increased. It was the day of two sessions. Girls insisted on going out to a near-by bakery at recess, and student council girls were stationed at different doors to prevent that. Girls patrolled the basement during the study hours to prevent steal ing. The student council looked after incoming freshmen and helped with order during re-organization. Associate student cauncil girls were elected in September of 1922 from all classes as follows: one English 8, one English 7, two English 6's, two English 5's, three English 4's, four English $3^{\prime} \mathrm{s}$, two English $2^{\prime} \mathrm{s}$. These were needed especially for chapel duty.

The most noteworthy step forward in democratic principles was the change in the method of election. It was necessary first to revise the constitution to take care of such a change. Accordingly under this revision, in 1922, every girl in the school was allowed to vote for the seventeen council members.

Miss Pauline Stein, a senior department teacher, says: The most democratic thing about the whole council (in 1922) was its method of election of officers. As closely as possible the election followed the scheme of our national election. To be eligible for an office a girl must have served on the Executive Board at least one term and must have been a member of English 4, 5, or 6 class. Each homeroom group discussed all eligible girls and made first and second choice by secret ballot. The representative and alternate, then acting as delegates, attended a regular convention. They made every effort to follow the plan used by a national convention, and two general tickets were finaliy decided upon. Campaign managers were then selected by the nominees. The se managers looked for good speakers. Anyone could make a speech, provided the speech did not

1 Miss Jane Wanless' talk on the student council made at the meeting of the Faculty League of Louisville Girls' High School. Written records of the L.G.H.S. Student Council, November, 1924 . 
exceed two minutes and the speaker said nothing derogatory about the other candidates. These speeches were delivered before an assembly of the whole student association several days before the election.

Reviewing the records of the Loulsville Girls' High School Student Council for January 10, 1922, we find a typical campaign speech as follows:

I want to speak for a few moments of a ticket which has Dora Allen for president and Mary Roach for vice-president. As Dora Allen has already been unanimously elected, there is no need to speak of her.

Everyone knows Mary Roach's splendid work on the student council. Many of us hear her every day in the basement directing traffic. We hear her calling to the girls and directing them, and somehow or other it doesn't seem to irritate us. We don't think she is trying to be bossy. We know" she's trying to help us. That is the kind of girl we need.

Mary has been in the city only two years. When she started out here in the freshmen class, she had practically no school friends at all. Since that time she has risen until she now occupies the office of President of the English 5 class, and why? Because her classmates realize her character and ability. That whole class of girls could not be mistaken! I myself am going to cast my vote for Mary, and all of you who wish to do what's best for the honor and name of I.G.H.S. will do the same.

At election time, posters and banners were placed throughout the school kuilding, and tags carrying the favored nominee's name were worn by her constituents. Interest ran high, because the honor to be bestowed was considered the greatest in the school.

A typical election is described in the records as follows: On election day, real polls were erected in the front of the auditorium. A printed ballot and facilities for stamping were supplied every girl. Real stamps and pads were used in the polis. A model registration, in charge of appointed election officers, was held, as the school file was placed near the polls. Each girl's name was checked of when she was 
handed a ballot. The polls were open from eight olclock in the morning until three o'clock in the afternoon of election day. Results were reported hourly on the student council bulletin boards until all voting had ceased. When the last official count and tabulation was completed, the results were posted on the bulletin board. A very impressive installation program followed, at which time the whole senior department was again called together.

Even the dafly newspaper took note of this forward step in democracy in a high school. The following extract is taken from an article appearing in the Louisville Times, January 10, 1922, "1400 Girls' High Pupils vote on Student Council":

An atmosphere of suspense pervaded the L.G.H.S. from morning to late afternoon Tuesday. That day, following a new mle, 1400 girls, comprising the school at large, voted for a president and vice-president of the student council... The election was an impressive lesson in citizenship.

other changes followed, until in 1925 the constitution was re-written entirely on a new and broader scale.

No minutes of the student councilwere kept until 1920. In looking over the minutes of those earlier years, the writer was convinced that matters of discipline formed a major part of the activities of the student Council, for the minutes seemed to show that much of the business of the council meeting was connected with matters of discipline. Severe was the punishment often meted out to the erring class or disobedient student that had been reported to the student council. The following extracts from the minutes tell their own story:

Deportment: English Fours to be taken out of chapel if 
no improvement in order.

December, 1922... Punishment for not obeying certain rules -- out of chapel for six weeks.

Sara did not tell her mother that she had to appear before the council, so the council president wrote to mother.

-..kept out of chapel for two months--changed her regular seat for another one with friend.

-.. kept out of chapel all of this term and next with the exception of Class Day.

-..did not appear before council when asked to, so she was given an extra punishment.

....kept out of chapel until she changes her attitude toward the council.

The following article, which was printed in the Record, the school paper, December 15, 1924, will show that student government was very popular.

In the good old days, in the days when the little red school house flourlshed, the rod of chastisement that dangled above the teacher's hand, was as much a part of the school furniture as the musty stove and the old tin dipper with the then undiscovered germ winking on the brim. The teacher who reigned over this ruddy institution of education truly reigned. He was a czar and acted with unique versatility as executive, legislator, and judge.... But gone are those days. That wielder of the scholastic birch rod has been sleeping with his fathers these many years.

The little red school house where he was wont to rule would have given place to a big red school house (so) little resembling its grandparents that the two seem hardly to belong to the same family. The rod, the sceptre of his authority, has, like the microbic tin dipper, departed this Iife. Symbols of power are absent. The one-man govermment is no more. Imagine the horror, nay, even the disgust, registered by the first whentold that the descendants of his subjects ruled themselves... We may imagine his asking as did the youth of Father villiam, "Pray how did you manage to do it?" We might reply that we did not manage to do it. Progress and civilization took care of it... In other words, the responsibilities of school govermment are put where they belong, upon the pupils instead of upon the shoulders of one man or one woman. The success of a democracy is dependent not upon the executive, legislators, or judiciery whom the people have elected, but upon the people themselves. If the student government falls, it is unsportsmanlike to blame 
the counclilors, for what are members of the council but the representatives of the students who elected them. The spirit of the erstwhile pedagogue would probably see that the pupils, like Times, had changed. They are no longer helpless creatures he had been accustomed to rule with an iron hand. He would realize that students, particularly those of I.G.H.S. are regarded as responsible beings capable of disciplining themselves. A greater compliment than this no student body can receive.

On further examination of the minutes of the student council from 1925 to 1934 (the date when the school moved into its new quarters at Halleck Hall) we note a gradual shifting of more responsibilities to the shoulders of the student councilors, who, by their co-operation, had proved their usefulness to the school in many ways. Mr. Samuel B. Tinsley, the principal of the school, cannot speak too highly of the inestimable value of the student council to him in aiding him in the management of the school. As he says, "I could not have got along without the work of the student councilors. They have been my right hand at all times."

The student council is constantly on the job. New duties are being added from time to time. Assisting with the traffic, ushering in chapel, acting as guides for visitors, assisting teachers in study halls and library, acting as guards at exits, having supervision of the lunch room are a few evidences of their aid to a smoothrunning school day . 
C. Present Administration and Organization

of Student Government

1. Organization of the All Student Association at Halleck Hall

The present organization of student government known as the All Student Association of Halleck Hall consists of two separate councils, the Girlst High School Student Council and the Loulsville Junior High School Student Council. The organization was effected to take care of the two divisions of the school which, though mun independently, must co-operate very closely in order better to carry out a smooth running of the school plant.

The transition to the new organization was not a difficult problem. The general set-up of the student council of the Girls' High School could fit very well into the plan of organization of the junior councll. The same constitution could be used to organize the All Student Association by amending the original constitution so as to include the junior division.

The senior student council could begin to function as soon as the school was opened in the fall of 1934, as its organization had been carried out at the old school in June, before the closing of the school year.

In the junior division, as all problems were new, student council objectives applicable to the local situation were carefully studied by a committee for a full term 
before a definite organization was effected. Even then the machinery was kept very simple and new 1deas were introduced gradually.

"The home-room unit is the logical starting point for the development of democratic participation in school government. Just as states are natural units for representation in our national organization, so home-rooms are logical units for representation in the student council." I Following such an accepted theory, the members of the two student councils at Halleck Hall are elected from the home-rooms (of which there are forty in the senior department and fifty-six in the junior department) by secret ballot. Each home-room elects one representative and one alternate; the latter is to attend any meeting of the council which the representative may be unable to attend. The members elected must be of outstanding character and have a scholarship average of at least 80. Any lowering of this grade, or misconduct of any kind on the part of a council member, drops the member automatically from the council. From time to time the requirements ha ve been raised. Meetings are held every Monday morning in the home-rooms from 8:35 to 8:50 at which matters pertaining to student council work are discussed.

Miss Stein makes the following comments on the set-up: The home-room organization itself is an integral part of

1 Harry C. McKown, Home Room Guidance, 1934, p. 165. 
the student council. The teacher, in whose room this Eroup meets, takes care only of administrative probleins; matters of discipline, matters pertinent to general school policies are handled entirely by the girls. A weekly meeting at wh ich the representatives take charge is held, minutes are taken by the alternate, who acts as secretary to the representative chairman. The teacher is not required to stay in the room unless she so desires. The representative reports back to her section any action taken during the regular student council meeting which has been held the previous week. There is always a full and free discussion. If any girl has noticed something of which she disapproves, or thinks of anything she believes might benefit the school, she asks the representative to carry back her suggestions to the council to be discussed and acted upon. The representative in turn brings back the results to her group. In this way, every one in the group feels she is an important part of the Assoclation.

In the junior department the home-room organization follows the same Ine of procedure in carrying out the policies of the junior student council. of course, on account of the immaturity of the juniors, the adviser has a greater responsibility. She must lend enthusiasm and inspiration to help the representative carry along the work. The fact that student council work in this division is relative new accounts sonewhat for the leck of success In a fev classes.

The work of the Association in both councils is carried on by means of similar corimittees on lunch room, assembly, library, traffic, care of the building, propaganda or publicity, etc.

So that each separate council would not infringe upon the rights of the other and at the same time that each would work in unison for the best interests of the whole school, an executive koard was created by the election 
of a certain number of students from the various sections and grades of the school. The constitution states that the members of the executive board shall be nominated by members of the class which they represent. As this executive board is a governing body and guides the policies of both the junior and senior councils, great care must be taken to secure the best material possible for board members. The sample form to be filled out by each candidate may be found in the Appendix, page 99.

The members of the executive board act as chairmen of the committees in their respective student councils, and as such, the chairmen report on the work of their committees at the veekly executive board meeting held each Mednesday from 2:35 to 3:00 o'clock. New policies are formulated which the chairmen of the committees carry back to their respective student council meetings the next day. The council hears the recormendations of the board, acts upon them, and, in turn, the home-room representatives carry back to their home-rooms the recommendations of their councils.

When the writer looks back on that first temn with no organized traffic patrol assisting in the passage of classes in the halls, she wonders that there were no more accldents than there were. Teachers were on duty in halls, lunch rooms, and playground. Every situation detrimental to the efficient operation of such an overcrowded school 
was carefully studied by the administrators. Committees were appointed, and finally the help of a properly organized junior student councll was enlisted. Today, the efficient work of the traffic patrol, lunch room squad, and recreation squad are splendid examples of what can be done in to co-operate in the smooth running of a school day. Of course, al ong with the actual service rendered by the council, the student body was being gradualiy educated to feel that they, as students of Halleck Hall, had become nembers of an All Student Association and must work in co-operati on with the organization, for therein, it was pointed out, lay the success of the whole structure.

The constitution of the All Student Association of Halleck Hall states as its purpose "to secure the cooperation of the entire student body in matters of conduct and discipline... also to foster a spirt of school loyalty and pride." With an idea of inculcating these virtues in the student body, the following school creed was adopted, and, at the yearly installation exercises of the newly elected officers, the entire student body is asked to stand and to recite 1 t.

I believe in the Louisville Girls's High School (or Louisville Junior High School) as a place where one grows in knowledge, in loyal co-operation, in loving comradeship, in honest endeavor, in gracious courtesy.

I, therefore, pledge allegiance to my school and believe it is my duty to love it, to obey its laws, to 
aid its sport and club activities, to champion its ideals so that its colors may fly over a school of ever widening influence.and deepening purpose.

Each home-room has a printed copy of the creed conspicuously displayed.

Student council members work hard, often with little publicity and not bedecked with any of the glory that other extra-curricular activities usually carry. At the senfor graduation exercises, however, the stadent councilors who are members of the graduating class are especially honored by being presented with a Student Council certificate, of which the following is a facsimile.

$$
\begin{gathered}
\text { S } \\
\text { The Principal, Faculty, and Students } \\
\text { of the } \\
\text { Loulsville Girlsi High School } \\
\text { wish to thank }
\end{gathered}
$$

for her loyal and efficlent services on the student council during the term

President

Chairman

Principal

2. Committees and Their Functions. The committees that carry on the work of the councils are: (I) Badge, 
(2) Inspection, (3) Cafeteria, (4) Recreation, (5) Chapel, (6) Propaganda, (7) Library, and (8) Traffic. There is a junior and a senior chairman with three or four homeroom representatives for each counc1l. In the junior division, the last committee is highly organized and forms a special department under the leadership of two members of the faculty.

The Badge Committee has charge of the inspection of all badges in the morning before school.

The Inspecti on Committee helps keep the corridors and lavatorles free from unnecessary paper.

The Cafeteria Committee supervises the three Iunch rooms. The only member of the faculty who has any connection with this supervision is the director of each council. The students are perfectly free to sit where they wish. Responsibility rests upon each student. Each student returns his tray of dishes and places all refuse in the proper receptacles. The student council chairman has a sufficient number of holpers to remind the students if they forget. It is a student Iunch room, and the students take pride in keeping it clean and orderly. No teacher has had to leave her lunch to supervise the cafeteria; the students manage it very efficiently.

The Recreation Committee, under the leadership of the gymnasium instructors and advisers, keeps order on the playgrounds and in the gymnasium at the lunch hour. 
The Chapel Committee has the work of ushers as its task. Eight or ten student council members direct the seating of the students and the dismissal.

The Propaganda Comittee has charge of all bulletin boards in the halls and special bulletin cases in the main corridor. In the senior department under the main bulletin board is placed a suggestion box where any girl may place sensible and helpful suggestions for the betterment of the school. The propaganda committee seeks to encourage all worthy enterprises for the good of the school. One of the busiest times is their direction of the advertising of the senior play or the junior opetetta. Song contests, limerick contests, feature contests in each room, and contests for ticket selling form a major part of their activities at that time.

The Library Chairman and his committee of one representative from each home-room assist in checking books, keeping order, distributing book slips for over-due books to the home-rooms each moming, and conferring on any problem that may arise in the library routine. A more detalled account of the work of the senior department chairman is found elsewhere. Additional work is necessitated by the use of the library as a "study hall."

The Traffic Patrol is one of the most necessary departments of the funior student council. Stationed at strategic points throughout the halls of the first and second 
floors, the patrolmen control the movement of the students and have authority to report cases of traffic disobedience to the student council. The patrol is headed by a captain Who is a member of the executive board. The patrol is divided into six squads, with first and second lieutenants and eight or nine patrolmen on each squad according to the needs of the respective station of the squad. Visitors often are amazed at the smoothness and ease with which the traffic moves. Especially was this true during the second semester of 1936-37 when the capacity of the building was further over-taxed because of the presence of an extra five hundred senfor girls who had to be housed in the building because of flood damage to their school plant. Membership on the patrol is limited to boys. A boy wishing to become a member goes to the traffic adviser and signifles his desire. An application card is given him ( sample in the Appendix, page 106). When he turns in this card properly filled out, the adviser makes a careful investigation of his qualifications, such as scholarship, habits of attendence, class and of fice record. If he is accepted by the adviser and there is no vacancy on the squads, he is then put on the reserve list.

Each morning from 8:15 to 8:25 the boys report to their first lieutenants. The boys' names are checked off the squad lists and their badges for the day given them. As 
a mark of distinction, the patrolmen wear an S.C. badge with an extra "T" on it on their arms. The traffic patrol takes its first position for duty at 8:40, the beginning of the first period. The patrolmen serve throughout the day during the changing of the classes, at the beginning and closing of recesses, and at the end of the school day.

A careful system of checking is employed each day by the captain and first lieutenants; the captain checks upon the six lieutenants, and the six lieutenants upon the eight or nine patrolmen in their respective squads. A possible score of 100 may be made each week by a member of the traffic patrol. Am average for each squad per week is turned in to the captain. The winning squad is rewarded by having its squad number displayed on its bulletin board. The following is a sample of the score sheet used by the first lieutenants in checking on their squads: 
Name of patrolman

\section{Squad} Week ending

Check list to be used by T.C. Officers.

Points

1. Attendance

2. Present for duty each time

3. Returning badges at end of day

4. Neatness and cleanliness

5. Good habits

- A. Does not use bad language

B. Does not smoke (use tobacco in any form) on school premises

6. Cheerful disposition

7. Courtesy in the administration of duties

8. No complaints from teachers or students

9. Does not use undue force upon any fellow student while engaged in the discharge of duties

10. Helps to keep halls tidy

11. Does not "show of f"

12. Does his part in protecting school property

13. Does not continually make excuses for his mistakes

S1gnature of reporting officer 
After each grading period the school reports of the patrolmen are turned in to the squad leaders. A failure upon a report card calls for a suspension during the next grading period. A fallure shown on a reserve member's card causes that boy to be stricken permanently from the reserve list. This plan of demotion has worked very successfully. During the first grading period of the second semester, 1937, flve boys out of sixty patrolmen were dernoted and all five were re-instated after the reports were given out for the next grading period.

The traffic patrol has worked out a manual of duties for the various officers and patrolmen. The following are the duties of a captain:

1. Take position in lobby of main corridor on first floor unless needed elsewhere.

2. Systematically inspect work of lieutenants.

3. Report any irregularities to the faculty adviser.

4. Take pride in your job.

Rules for lieutenants (first):

1. Inspect badges and check attendance daily, 8:20-8:30.

2. Report promptly to your corridor.

3. Vatch work of your patrol.

4. Substitute men for absentees.

5. Serve wherever you are most needed.

6. Ask one teacher on your corridor to act as an adviser to you and your patrol.

7. Keep a written record of your men's attendance and work.

8. Remember you are responsible for your corridor.

Rules for lieutenants (second):

1. Substitute for first lieutenant if he is absent.

2. Study the traffic situation in your particular position.

3. AlWays occupy your assigned position.

4. Report to the first lieutenant any difficulties. 
The following were worked out by the traffic patrol and enforced by the patrolmen on duty:

Rules for traffic in main corridors:

1. Never cross the hall.

2. Always keep in the stream of traffic.

3. Students passing on the stair side of the hall move east only.

4. Students passing on the opposite side of the hall move west only.

5. If necessary, walk to the brass crossing at the end of the hall and pass around S.C. guard stationed there.

6. Follow the arrows.

7. Do not cross the hall at library entrances.

The patrolmen wear badges as follows:

First Iieutenants:

Black "T" with two chevrons on gold shield. Sec ond Lieutenants:

Patrolmen:

Black "T" with one chevron on gold shield.

Black " $T$ " on gold shield.

The School Boys Patrol is on duty at all of the corners of the block in wich the school is located. The chairman and his patrolmen are all members of the School Boys Patrol of the city. It is a matter of great pride to the boys that there has not been one serious accident since the opening of the school four years ago. The chairman of the School Boys Patrol is a member of the executive board.

The use of study halls in the senior division has necessitated specialized duties for the committee in charge. The following rules have been set up:

Councilors shall be placed:

1. At the study hali door.

2. Opposite the stairs by the small cafeteria.

3. At the intersection of the cafeteria corridor with 
the main corridor.

4. Outside the library door.

5. Inside the library door.

Duties of student councilors $I$ and 5 are as follows:

No. 1:

a. Reach her post of duty promptly.

b. Issue S.C. tickets to girls to be excused to go to lavatory.

c. See that tickets are returned within four minutes.

d. Keep in a special book the names of the girls who are excused.

e. Report any irregularities to the teacher in charge.

No. 5 :

a. Reach her post of duty promptly.

b. See that each senior student receives a slip.

c. Collect slips and take them to the study hall teacher five minutes after the beginning of the period.

d. At the end of the period, see that the students place materials where they belong.

e. See that the chairs are pushed in place under the table.

D. Typical Activities of All Student Association

The work of the AlI student Association today is a far cry from that of the early councils, when the student body, with the help of the student council, "was to be responsible for discipline in the halls, on the stairs, in the chapel and in the lunch-room."I

Today, the student council work permeates the whole life of the school. What any one wishes to "put across" in the

1 Jane Wanless, "Student Activities Teach Self-Discipline," The Loulsvilie Times, October,20, 1922. 
school is best done if worked through the student councll. They conduct "Who's Who Week" at the beginning of the term to acquaint the students with each other and with the teachers. This is followed by "Perfect Speech Week," "Better Attendance Week", "Clean Bullding and Yard Week," and "Clean Up Week," which is in co-operation with a citywide "clean up" campaign held each spring. Each of these is in the nature of a contest. Then there are the antinoise campaign and various other campaigns that tend to make students discharge better their responsibilities as citizens in a school democracy. Several of these are reviewed below: A very interesting campaign, "Passage in Halls," was carried on successfully during the last semester of 1936. Because of the flood conditions, the capacity of the school was overtaxed by an additional five hundred girls. Traffic in the halls naturally was congested, and rigid rules of passing had to be enforced. Traffic had to move from west to east on one side of the hall with no crossing of the line opposite the door of the desired room until the end of the hall was reached.

On Monday morning, the first day of the campaign, each student was issued one ticket-- the object being to retain that ticket unsurrendered during the week of the contest. The traffic guards were authorized to ask a student for his ticket if the student was seen crossing at the wrong place or running in the halls. If a ticket has been surrendered 
previously on that day, the offender's name and section were taken. At the close of the day, all confiscated tickets were turned in by the traffic guards to the the student council chairman; a check was made against the home-rooms; then the confiscated tickets were returned to the owners the next day. The pupils of the homerooms took pride in trying to be one hundred percent perfect in retaining all tickets unconfiscated. Running in the halls and cutting across at the wrong place were greatly reduced and a more orderly passage in the halls resulted.

The question of chewing gum had often been brought up during the student council meetings. Finally, it was decided to get out a bulletin which the student council representative could use for discussion in his home-room class. The following is the bulletin 1ssued March 19, 1936:

1. What is chewing gum?

2. When the sole of one's shoe comes in contact with a piece of chewing gum on the floor is the result plèasant?

3. Do you like to drink from a fountein that has chewing gum sticking in it? Does the presence of the chewing gum improve the taste of the water?

4. Do you like to touch a piece of chewing gum stuck under the arm of a chair or under a table? How can this be avoided?

5. Did you ever try to remove chewing gum from your coat or dress? Was it easy? How can this difficulty be avoided?

6. Do you like to see people chew?

7. When do people resemble cows? Do you like to resemble a cow? How can this be avoided? 
During "Clean Up Week" the student council put on a locker inspection. At a designated time during the week all students go to their lockers, open them, and remain standing beside them while they are inspected by a student councilor. Simple directions have been given each councilor, and he has a report blank which is to be filled out and turned in to the locker inspection chairman. A check is made of all untidy lockers, and a return inspection is made later to see that they pass inspection. The following are the directions to the inspector:

LOCKER INSPECTION

Name of Inspector

Directions .

Inspect lockers.

You need not list satisfactory lockers, but write in the following columns the numbers of lockers closed or untidy, or containing overdue library books. Take all library overdue books to the library.

\begin{tabular}{l|l|l|l} 
No. of tidy & $\begin{array}{l}\text { Closed lockers } \\
\text { No. of locker }\end{array}$ & $\begin{array}{l}\text { Untidy lockers } \\
\text { No. of locker }\end{array}$ & $\begin{array}{l}\text { Overdue books } \\
\text { Found }\end{array}$ \\
\hline
\end{tabular}

The following extracts are taken from a safety bulletin issued by the Student council in co-operation with the "National Safety Week" campaign. Student councilors were asked to present it in their home-rooms. 
The Need for Safety in the Home

Councilor and Alternate will enact charades demonstrating the following:

1. Mouse nibbling matches.

2. Person with wet hands turning on electricity.

3. Electric iron causing fire.

4. Use of electric attachment in bad condition.

5. Baby putting hand in open floor socket.

6. Carelessness in turning off gas.

7. Books and toys left on floor.

8. Cleaning gloves with gasoline, and six other demonstrations of like character.

One campaign, carried on in the Junior division only, was a campaign for better attendance. The following extracts are from a home-room bulletin.

Topic: Better Attendance in Halleck Hall.

Introduction: The attendance problem is a serious one in Halleck Hall. Our aim in the Attendance Drive, which will continue from March 27 to June 5, is to have not perfect attendance but better attendance. The success of this campaign depends not alone on the Attendance Committee and the Student Council, but upon each teacher and each Home Room Class.

1. Work out appropriate attendance slogan, hand it to At tendan ce Commit tee.

2. Create an attitude and desire for the Better Attendance Drive.

3. Display some sort of chart or graph to boost attendance.

4. Telephone or make personal visits

5. Discuss and urge friendly rivalry between your students and those in other rooms.

Information for classes.

1. Classes with the winning slogans will be awarded the school flag to display for a week in their class rooms.

2. Classes with the lowest absence record will be awarded the Attendance Stars to display on doors. The student Council w1ll have these ready for use next Monday. A different color is being used for each section of the three junior high grades. 


$\begin{array}{ll}\text { Yellow - 7B } & \text { Blue }-8 A \\ \text { Orange }-7 A & \text { Green }-9 B \\ \text { Rose }-8 B & \text { Red }-9 A\end{array}$

Each star displays, in addition to the words "Better Attendance," the following letters: $R, P, C . E$, and $S$. These represent the following: regularity, punctuality, co-operation, effort and school success.

Suggestions for use in home-room programs:

1. Work out a class outline on the following:

"Advantage of Good Attendance,"

a. To the individual student

b. To the class

c. To the school

2. Talks on topics similar to this one: "It pays to be regular and punctual."

3. Display your elass slogan on your bulletin board.

4. Encourage the making of graphs showing progress in attendan ce.

5. List any suggestions your class thinks might be used successfully in the junior division.

The classes were interested in bringing up their attendance, and at the end of the contest the attendance was greatly improved, showing that the endeavor was worthwhile.

One of the most recent activities undertaken by the junior student council is the traffic school, managed by the senior department traffic chairman. An increasing number of accidents, some slight and in a few cases serious, had been occurring during the passing of the classes in the halls. Such accidents were traceable to undue haste on the part of the students. The traffic department, after careful consideration, decided that it was expedient to have better co-operation from the pupils to eliminate all accidents. 
When a trafic guard sees a pupil muning in the halls during the passing of the classes, the offender's name and section are taken and a ticket to report to the next traffic school is given him. The guards turn in the nanes of the offenders to the traffic chairman. On Friday, at the close of school, the offenclers assemble for instruction. A set of traffic rules to learn and recite at the next meeting is given each pupil. The number of offenders having to report to traffic school has decreased very greatly during the several weeks of its operation. A noticeable reduction of running is evident, and the number of accidents has been reduced to zero since the establishment of the traffic school. The traffic department hopes soon to abandon the traffic school until the need for it may arise in the future.

One of the activities undertaken during the Fall semester of 1937 was directed toward a better understanding of the constitution as a working basis for the All student Association. A special bulletin was issued which contained information on student government in Halleck Hall and a catechlsm on the subject (see Appenaix, page 100). Two weeks were given in which the students could discuss the material in their home-rooms and learn the facts intelligently, so as to pass a test given later (see Appendix, page 103). The finished papers were sent to the student council advisers, who had student councilors to check each paper carefully, find the median of each class, and return the papers to the proper. 
home-rooms for pupil inspection. Later, the same test will be repeated, as the result of the recently given test was unsatisfactory. In this way it is hoped the student council work will be understood more clearly by all students, and fuller co-operation will result.

During the first semester of 1935-36, an especially interesting series of personality lessons for the senior department was held once a week over a period of five weeks. This project was prepared and carried out by the Student Council with the help of the adviser. The president presented the material to the councilors as she hoped it would be presented to the home-rooms by them. The following is a detailed outline of the plan.

\section{Personality I}

Aim:

Pupils will become aware of their own personalities as far as appearance, poise, speech are concerned and will endeavor to Improve themselves in the high schools.

\section{Appearance}

What would be in "appearance?"

Suggestions: Cleanliness, arrangement and care of hair, nails, carriage, dress (neat, flashy, sloppy, becoming, suitable, properly, thrown on). Have you a correct idea of your own appearance? Would you dare to ask a person whose opinion you value to give you a criticism of your appearance? Would you profit by it or would you resent unfavorable criticism?

Take three minutes each morning to study yourself in the mirror. 
Ask yourself this question: "If every one in the class looked as neat and attractive as I do, would I like to look at the class?" If you do not like your appearance, suggest ways you may remedy it.

\section{Hair}

What can be done about your hair?

Study simple attractive methods of arranging the hair and perfect yourself in one that is becoming, taking care that the hair is clean and well-brushed.

\section{Dress}

Does the dress that is ripped or torn or has buttons or fasteners missing look attractive? See that there are no rips or tears in your clothes or no buttons missing.

Do clothes that are jerked on carelessly and hurriedly look their best? Take time and pains to put your clothes on properly.

Are wrinkled or mussed clothes an asset to the wearer? Press your clothes then they need it.

Do well polished shoes with stralght heels add to the attractiveness of one's appearance? Keep your shoes clean and polished and have the heels straightened or renewed when necessary.

Which is worse, nails that are broken, dirty and uncared for or nails that are so conspicuously manicured and polished that they attract attention? Keep your nalls clean and carefully inconspicuously manicured. Home Economics courses will help you on this.

\section{Carriage}

Do girls that hold their heads up and shoulders straight and walk well seem to have more control over themselves than girls who walk with their heads down and shoulders drooping and drag their feet? Take gymnasium work. Consult the gym instructor for advice as to correct exercises. Study physiology. Talk with the health counselor.

\section{Speech}

Does the fact that you are sure of your English give you confidence in yourself and make your personality more compelling? Does the knowledge that you make a "break" in English at any time cause you to be self-conscious and less prepossessing than you otherwise would be? 
Suggestion

Master the rules governing "good usage." Cultivate friends that speak good English. Ask some friend to correct you when you make mistakes. List the common errors of which you are gullty and eradicate them one at a time. Study English ahd foreign languages.

\section{Voice}

Have you a pleasing voice? Ask your English teacher. (Study dramatics, public speaking, volce.) Keep your conversational tone low. Open your mouth wide when you talk. Are you timid? Afraid of the sound of your own volce?

\section{Suggestion}

Make yourself participate in discussion in all classes. Volunteer to make reports in English and History classes. Try to be more interested in other people, and forget yourself. Make new friends. Avold associating with the same little group all the time. Take pains to have something to talk about.

\section{Aids} you.

Class room discussion in history particularly will help

Express your opinion in the student organization meeting in your home-room.

Particlpate in group games in school and out.

Join one or more school clubs and use every opportunity they afford to express yourself.

Help with social functions.

Poise

What is meant by poise? Is it an asset to personality? Does it make for personality? What factors mist one develop to acquire it?

\section{Suggestion}

Consciousness of attractive appearance, good manners, correct speech, knowledge of ordinary information familiar to most educated people will aid in acquiring poise. Is it true that the more knowledge one acquires the less apt she is to be found at a loss in any society? 


\section{Project}

Nake a chart of your school day by periods including chapel period, lunch, and library periods. Beside each, state what opportunity the subject studied or the activity engaged in or the association with companions affords for improvement of your personality. Talk to your teacher about it and conscientiously strive to take advantage of each opportunity daily. At the end of the week make a statement of what you have done for your personality each period of the school day.

\section{Personality II}

Aim:

The students will become aware of attitudes and habits that interfere with success and try to rid themselves of such attitudes and habits.

Attitudes that interfere with a successful or pleasing personality:

I. Inferiority complex.

II. Overly sensitive feelings.

III. Hypercritical feelings.

IV. Lackadaisical attitude.

V. Whiney volce.

Habits that interfere with a successful or pleasing personality:

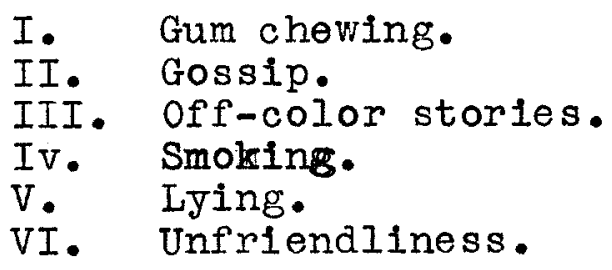

The reaction of one of the teachers toward the project is reflected in the following comments:

The girls attempted to define personality and every girl offered suggestions for her own improvement, and the general improvement of others. Dress, cosmetics, posture, pleasant mannerisms, etc., were discussed. In one home-room, each girl stood before the class and allowed the members of the group to write out in detall any criticism or compliments 
which they thought might give her a better personality. None was signed and no one saw them except the writer and the recipient. Since this was a group of thirty-five good school friends, the result was excellent. The teacher noted during the following two weeks that one mousy, unattractive little girl had acquired a permanent wave and a much clearer face and had stopped chewing gum; another stopped using mascara on her eyes; while still an other, whose posture had been bad, asked permission to join $a$ gymnasium club.

To summarize some important points of the chapter we note: Halleck Hall All Student Association has a simple, workable plan whereby the whole student body is given an opportunity to practice citizenship through co-operation in worthwhile projects sponsored by the association. Much of the success of the association is due to the "trial and error" of the twenty-one years of work of the senior student council. We note that the work has not been static but new me thods have been introduced from year to year to make the work more vital and democratic. The typical activities show that many opportunities have been used to enlist helpful co-operation of all the students toward making them better "citizens of tomorrow." 


\section{CHAPTER IV}

AN EVALUATION OF THE PROGRAM AT HALLECK HALL 


\section{CHAPTER IV}

\section{AN EVALUATION OF THE PROGRAM AT HALLECK HALL}

A. Criteria of a Successful Program

The value or worth of student participation in school evernment at Halleck Hall largely depends upon two general criteria: (I) the service the organization renders the school and (2) the service the organization renders the student.

Let us consider the first criterion mentioned ahove. It may be resolved into several more specific criterie such as the following: Is there a real need for such an organization? When we set up this criterion we have in mind the question, Is there any need for the existence of student participation in school government, or is it just another activity? Student participation in school sovernment at Halleck Hall is a natural growth in educational procedure and is the result of a changed social-educational order. To meet these changed conditions, as a fundamental, Halleck Hell has become a center for training in leadership and service, not only for adult life, but in the living present school Iife.

The All student Association was organized to meet a felt need rather than to impose a definite prosram upon a student body by an over-zealous teacher or a principal fired with enthusiasm for organization. As a corollary to student participation in the Halleck Hell government being a felt need, 
naturally, it has the endorsement of the administrative head and the majority of the faculty. This purposeful activity, therefore, meets a real need in the school organization. It has grown out of existing life situations in the general routine of the smooth running order of a school plant. It has had a gradual growth with increasing responsibilities as the need arose, thereby fulfilling or justifying its existence to a great extent.

But not only should such an organization meet a felt need; it should meet that need in the most efficient, economical, and acceptable manner. Therefore, such questions as the following seem pertinent: Is it simple, workable, adaptable, democratic? Does it most nearly meet the needs of the school in realizing the purpose that the school had as an objective in the establishment of such an organization? When we consider the simplicity of the set-up at Halleck Hall and the ease of its operation, with its proved adaptability to new situations, l we realize that it satisfactorily measures up to these criteria, too.

The worth of any plan is its practical application. Student government does work efficiently at Halleck Hall. One has only to step into the halls of the school for a

I The adaptability of the organization was proved most strikingly during the spring term of 1937 when the capacity of the building was further taxed by the presence of 500 additional students from a flood damaged school. 
short time to see one of many practical demonstrations of its worth through the medium of the traffic patrol, as they direct the passing of the classes in the halls.

Let us now consider the second criterion: the service the orgenization renders the student. This criterion may be resolved into the following questions.

1. Does student participation in school government at Halleck Hall meet the needs of its students? Greater interest will accrue because it is in the realm of his experience if the activity is closely related to his life.

2. Does student participation provide for social development? Included in this question is the idea of co-operation, understanding, and sharing of responsibilities through the discharge of certain obligations in the social grap.

3. Does student participation in school government provide opportunity for the students to learn to evaluate, weigh, accept, or reject as the situation arises?

4. Does student participation in school government have leading-on qualities? By this we mean, will the pupil gain an $\mathrm{y}$ experiences that he may want to use later in Iife, thereby enriching his life?

In the Ilght of what the best educators have written on the subject, the organization answers each of these questions satisfactorily. It is difficult to think of any activity more intimately involved in the student's school life than 
the government of his school. The devices of popular election and discussion are certainly fraught with possibilities for social development. The organization is predicated upon on active, interested study body, and its continued operation would indicate that such exists. In alding the efficient management of the school, the organization, of course, is rendering to each individual both directly and indirectly a very valuable service. Efficient management, however, ought not to be considered the most important contribution of the movement to the individual's well-being, for it may be possible, though in the opinions of such well-known educators as Fretwell, Mckown and Earle Rugg, it is unlikely, to attain an even greater degree of efficiency under some system which eliminates the machinery of popular elections, home-room and student council meetings, etc. It is just in these devices the these educators see the chief service rendered by the student government movement to the students. Comments of the students and the faculty show in many cases a complete agreement on this point. By providing opportunity for practice of the democratic wy, the movement is rendering the students a most important service.

A democratic organization implies an organization which provides an opportunity for the student to make conscious choice. The student council at Halleck Hall does nrovide 
abundant opportunity for such experience, from the first step of electing its members on through the free discussion in the council meetings and home-room meetings. Included in the idea of democracy for the students is the idea of providing an opportunity to share experiences with each other, or, as Kilpatrick so ably states it, providing "for co-operation in ever-widening social groups." I Through this co-operation good citizens seemingly being made at Halleck Hall, are citizens who will share responsibilities in their communities and make their communities better because they have lived in them. Halleck Hall Student Council, therefore, through its democratic principles, seeks to develop the individual and at the same time to work for the velfare of the whole student body.

The writer, by means of a check list and interview, has sought to learn the opinion of many members of the faculty and the administrative staff, in addition to the student body, on this question of the value of student participation in school government. Sixty Halleck Hall teachers were asked to fill out a check list. The replies were tabulated as follows:

1 W. H. Kilpatrick, "Educetion for Adolescents for Democracy," Religious Education, 19:123-35 (June, 1919) 


\section{TABLE V}

Some Practical Advantages Derived From Student Participation in Halleck Hall School Government as Revealed by an Analysis of Sixty Replies From the Teachers to a Check Iist Dealing with the Topic

Does Student Participation in School Government at Halleck Hall:

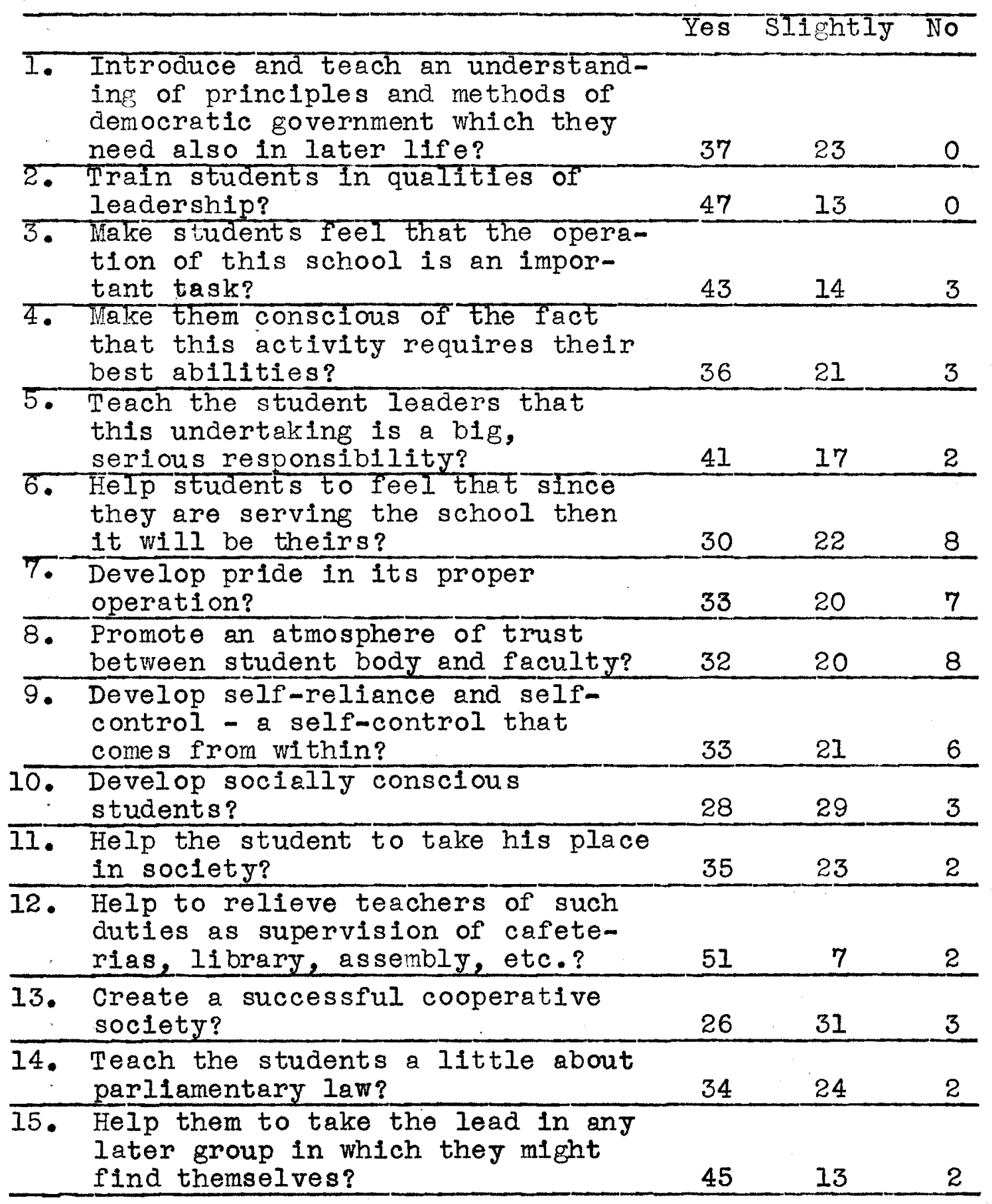


TABLE V (con)

\begin{tabular}{|c|c|c|c|c|}
\hline - & & Yes & SIightIJ & No \\
\hline I6. & $\begin{array}{l}\text { Encourage a greater interest in } \\
\text { knowledge of government? }\end{array}$ & 20 & 37 & 3 \\
\hline 17. & $\begin{array}{l}\text { Help the students to make the } \\
\text { school a better place in which } \\
\text { to work, play, and study? }\end{array}$ & 42 & 16 & 2 \\
\hline 18. & $\begin{array}{l}\text { Train in independence of } \\
\text { thought and action? }\end{array}$ & 27 & 28 & 5 \\
\hline & $\begin{array}{l}\text { Train in practice of sane } \\
\text { judgment and common sense? }\end{array}$ & 30 & 25 & 5 \\
\hline$\overline{20 .}$ & Develop good sportsmanship? & 32 & 23 & 5 \\
\hline$\overline{21 .}$ & $\begin{array}{l}\text { Make the student better able to } \\
\text { resist temptation in college } \\
\text { or business? }\end{array}$ & 21 & 32 & 7 \\
\hline$\overline{22 .}$ & $\begin{array}{l}\text { Give students an opportunity } \\
\text { to profit by mistakes made? }\end{array}$ & 35 & 20 & 5 \\
\hline & $\begin{array}{l}\text { Help the student to act } \\
\text { quickly and efficiently? }\end{array}$ & 30 & 24 & 6 \\
\hline & $\begin{array}{l}\text { Help students to rise to } \\
\text { greater responsibility in } \\
\text { higher education and in } \\
\text { business? }\end{array}$ & 29 & 24 & 7 \\
\hline$\overline{25}$ & $\begin{array}{l}\text { Develop poise and charm of } \\
\text { manner? }\end{array}$ & 40 & 15 & 5 \\
\hline 26. & $\begin{array}{l}\text { Enrich the student's } \\
\text { experience? }\end{array}$ & 36 & 18 & 6 \\
\hline & $\begin{array}{l}\text { Do the advisers give the } \\
\text { adequate proportion to } \\
\text { student initiative? }\end{array}$ & 39 & 13 & 8 \\
\hline 28 . & $\begin{array}{l}\text { Should the student Council } \\
\text { have more disciplinary power? }\end{array}$ & 9 & 6 & 45 \\
\hline 29. & $\begin{array}{l}\text { Do the student councilors } \\
\text { as sume too superior an } \\
\text { attitude? }\end{array}$ & 10 & 17 & 33 \\
\hline 30 . & $\begin{array}{l}\text { Have the proper amount of } \\
\text { emphasis placed upon activi- } \\
\text { ties sponsored by the council? }\end{array}$ & 37 & 6 & 17 \\
\hline
\end{tabular}

From Table V we note that the "yes" column is decidedly the weightiest except in a few items in the "slightly" 
column and "no" column. One noticeable item in the "slightly" colunn is the item, "encourage a greater interest in knowledge of government?" Under itens in the "no" colum the two weightiest ones are the items, "should the Student Council have more disciplinary powers?" and "do the student councilors assume too superior an attitude?" This table concurs rather closely with what the best educators on the subject have so stated in their findings. Miss Elizabeth Robertson, a member of the senior faculty who has seen the student council grow from its infancy to its present larger usefulness and who has been an adviser to the Council, enthusiastically endorses the services the organization renders the student. She writes:

The All Student Association is one of the most helpful agencies for the development of both boys and girls in high schools.

1. The fact that a boy or girl has a definite obligation resting upon him for fulfilling a duty is in itself of infinite value. This obligation will bring about a development not only along the lines of loyalty but also those of independence as well. For a boy or girl to feel that he is responsible for a certain job creates in him a desire to do his best.

2. The student council offers just the kind of responsibility that the pupil needs. The working together of the leaders and the members brings about a co-operation that tends to make one do his best for the general good of all.

3. The fact that the student council in Halleck $\mathrm{Hall}$. is so organized that every member has a chance to help in some way is of great value. The leaders of home-room groups develop into excellent leaders before the year is over.

4. To have a part in the working of the school develops loyalty as well as independent thinking. Once a group of school students begin to make suggestions for improvement along certain lines, enthusicsm increases and the general 
trend is lifted. Anything that a boy or girl can do to bring the school closer to his school life helps him just that much more to reach higher levels of thought. The fact that, success brings success is at the root of the activity. If a boy or girl does anything well, he or she will like to do something else well. It is just this that I think is at the heart of the student council worl: of Halleck Hall.

The replies of 275 senior students when asked for their opinions of student government as functioning at the school clearly fall into three marked graps. Two hundred and fifteen definitely committed themselves as being strongly in favor of student participation in school government, as shown by a few typical answers:

I think It's very good. I've only been in this school about a year and in the other two high schools I've gone to there wasn't anything like this. It was all teacherruling. It's more fun when girls have some say.

I think student government is fine because it gives the girls on the student council a chance to learn how to meet people, how to address a group of people. It gives the rest of the girls practice in electing people who they think will make the best leaders.

I think the Student Council government at Halleck Hall is a good thing. It teaches one to obey rules and this is a thing one will have to do all through life, such as in traffic and in other things.

I think the student government at Halleck Hall is very good. It teaches the students to think for themselves. It also teaches co-operation among the students. I think the student government here is very good.

I think the student government at Halleck Hall is very good, and efficient. It promotes good order among students and gives everyone the feeling that they have a part in their school.

I came from a school in another state but I'm sure that the student council of L.G.H.S. far surpasses all the student government bodies that I have been associated with.

I think the student council government has proved to be very efficient. It causes the students to be more interested 
in the school activities, and the students will be far more apt to obey the various rules made.

I think the student council government is good because the whole student body would be in a complete uproar without it. It makes good citizens out of the pupils. It saves time in the lunch room and in the halls while we are going from class to class.

I think student government is an excellent way to govern a large school because the students theinselves realize that the success of the school depends largely upon them.

Forty students were in favor of the student government, but with frank reservations or criticisms such as the following:

I think the student government is good as a whole, but every student doesn't get a chance to get on the student council. Some students are student representatives three or four times in succession. It makes the other students feel inferior because they have to look up to the representatives.

I think the student council is very good, as long as the members don't try to boss you.

I think the student council would be all right if the student councilors would obey the orders they give as well as expect us to obey them.

The student government is a very helpful project to I.G.H.S. Although I do think there is too much authority exercised by the students on the council.

I think the student government is a very good method to work under, although I think too much importance is attached to girls who are elected to help in running it. They deserve a certain amount of honor, but they attach too much importance to themselves.

I think the government is a good idea. But the girls should have more to say about the way it is run.

I think the student government is very good in some ways and rather stupid in other ways. The adviser has rather a large part in the governing--too much in fact. 
I belleve the student council is in a way a help to the school. I think it has its good points and al so it has its bad points. Some students have the wrong impression of it and, therefore, try their best not to co-operate. I have never been so enthusiastic about it, although I think the school is run much more smoothly with it.

Twenty students were openly opposed to student government, as shown by the following criticisms:

The student councilors think they are superior to the other girls.

They take too much authority in their own hands.

I know that some of the girls do not keep the rules they insist on us obeying.

I think it is a teacher-pet showing off. I think the school would be a lot better without it.

The student council is not an organization that helps the students materially; therefore, I do not believe it is any good.

I think the student council has a very poor system. The councilors are so strict that it makes it more like a prison than a school. I realize that it may be necessary to have a traffic school, but it is too strict; one is sent for the slightest thing.

Some people take advantages of their badges too much.

Miss Ethel Bauer, graduate of the senior high, who served as president of the student council for one year, 1934-35, and as a member of the executive board for three years, makes the following comments upon the value of student council work to her:

In every person's life there is usually one experience that stands out more than any other. In my life I consider the three years I spent on the executive board of the student council to be the most instructive and enjoyable ones I have yet lived. Those six terms were filled with numerous duties that of ten carried a great deal of responsibility with them. The most important office that I held was the presidence of the student counc1l. The 
president is often called upon to give speeches in assembly and to preside over meetings at which the entire student body is present. When I gave my first official speech, I was, frankly, almost "petrified." At the end of my year of office, I was much more self-confident and at ease on the platform. This is only one of the privileges offered a nember of this organization. Twice I was an officer of the city for a day; once I was a member of the Board of Education and another time I was a Director of Welfare. At such times I met quite a number of people important in civic affairs. Those were delightful experiences in themselves.

However, I must confess that at times we members became discouraged and worried over the problems that we were trying to solve, and often things didn't run according to plan, but these troubles only helped the more in showing us how to cope with different problems and difficult situations.

I loved being on the student council those six terms. It was my high school life. I truly wish that every student could serve on an executive board of a student council such as we had at the Louisville Girls High School. I'm sure the students would never forget their profitable experiences. I never shall.

Junior students were asked to fill out a check list on the value which student participation in school government has for them. The replies were tabulated as follows:

\section{TABLE VI}

Some Practical Advantages Derived from Student Participation in Halleck Hall School Government as Revealed by an Analysis of 500 Replies from Junior Students to a Check List Dealing With the Topic:

\begin{tabular}{|c|c|c|}
\hline Rank & Advantrges & $\overline{\text { ency }}$ \\
\hline 1. & Helps to direct trafic in the halls & 425 \\
\hline & $\begin{array}{l}\text { Help s to make the lunch room cleaner } \\
\text { and more orderly }\end{array}$ & 418 \\
\hline 3. & Helps to direct outside traffic & 387 \\
\hline 4. & Glves the pupils a volce in the covernment & 337 \\
\hline 5. & Makes better citizens & 297 \\
\hline & $\begin{array}{l}\text { Helps to keep the building free from } \\
\text { waste paper }\end{array}$ & 269 \\
\hline 7. & Develops leadership & 248 \\
\hline 8. & Teaches co-operation & 200 \\
\hline 9. & $\begin{array}{l}\text { Thakes the school a happler place in which } \\
\text { to work, play and study }\end{array}$ & 9 \\
\hline
\end{tabular}


TABLE VII

Some Disadvantages of Student Participation in Halleck Hall School Government as Revealed by an Analysis of 500 Replies From Junior Students to a Check List Dealing with the Topic

\begin{tabular}{|c|c|c|}
\hline Rank & Disadvantages & Frequency \\
\hline 1. & Students use too much authority & 178 \\
\hline 2 & $\begin{array}{l}\text { Students take their duties too } \\
\text { lightly }\end{array}$ & 173 \\
\hline-3. & $\begin{array}{l}\text { Students do not have proper respect } \\
\text { for councilors }\end{array}$ & 132 \\
\hline 4 & $\begin{array}{l}\text { Students do not co-operate with } \\
\text { councilors }\end{array}$ & 85 \\
\hline 5. & $\begin{array}{l}\text { Councilors use their power wrongly } \\
\text { to get honors }\end{array}$ & \\
\hline 6 & $\begin{array}{l}\text { Councilors seem to think themselves } \\
\text { superior }\end{array}$ & 51 \\
\hline 7. & $\begin{array}{l}\text { Some councilors do not prove capable } \\
\text { leaders }\end{array}$ & 43 \\
\hline
\end{tabular}

Mr. Samuel B. Tinsley, principal of the school, makes the following comments upon the service the student council renders to the school and to the pupil:

The Student Council develops such traits and attitudes as loyalty, co-operativeness, leadership, initiative, respect for and care of public property, keeping the school informed regarding matters and indications of good citizenship. The school government is primarily concerned with development of school leadership and service that will enlist pupils in support of good house-keeping, thrift, health, recreation, beautification, etc. It assists in directing traffic, promoting safety, and protecting property.

Pr. William Coslow, assistant principal in charge of the junior section, states that he is constantly placing more and more responsibility upon the student council, as he realizes that the council is proving its worth as a means of promoting the best interests of the school. He also says that the Student Gouncil with its home-room representation affords the 
best means of securing the co-operation of the student body and at the same time is training the students in citizenship in a school democracy. No large school, and surely not Halleck Hall, can successfully carry out a well-rounded school program without enlisting every pupil's co-operation to the fullest extent.

Dr. Zenos E. Scott, Superintendent of the Louisville Public Schools, reports that he is in hearty sympathy with student council theory and practice. He says that, as a superintendent, it is his function to be acquainted with the student level of the organization. He further remarks that student council work in the future should be an important agency by which students can practice good citizenship in their school life.

In 1937, Halleck Hall was very highly honored by being one of the four schools of Kentucky included in the co-operative study of secondary school standards. The survey of Halleck Hall was conducted by Mr. Paul Rhemus, principal of Battle Creek High School, and Dr. William Iversen of Leland Stanford University. For a period of one week, January 11-15, the school plant was carefully studied. Preliminary work consisted of a set of very detalled questionnaires which were to be

I

See G. E. Carrother, "The Cooperative Study of Secondary School Standards," School and Soclety, 45 :597 (May, 1937). 
studied carefully and filled out by the administrative force with the co-operation of the entire working staff of the school. One questionnaire dealt with the pupil activity program ( see Appendix, page 108).

Mr. Rhems and Dr. Iversen, besides being vitally interested in the class room work of the teaching staff, were especially interested in the student council activities of the school. They visited the regular weekly meetings of the senior council and the executive board. They also had personal interviews with the various officers of the Association and throughout the week saw the student body actively participating in the school government. The following comment appeared later in an article by $\operatorname{Mr}$. Rhermus: ${ }^{I}$

Excellent Student Councils in North High, Des Moines; Louisville Girlst...

As a starting point for all their investigation, the committee asked for the philosophy of the school to be stated. It vas stated in the following terms:

We believe:

1. That moral and ethical values are permanent.

2. That mental honesty, as well as honesty in material things, is necessary for happiness...

3. That the intelligent pers on is...the well-informed person.

4. That the fuliness of life is attained through social intelligence with a desire for social good.

1 Paul Rhemus, "Philosophizing Enroute," Education Digest, 111:31 (September, 1937). The actual results of the survey at Halleck Hall are not as yet available, as the material turned in by the examining committees is still in the process of compilation. 
The writer would be very remiss in evaluating the situation of student participation in Halleck Hall government should she ignore the criticisms directly or indirectly made above. She feels that student government measures up to the stated criteria in a very satisfactory manner, but, like any plan dealing with immature students, it cannot be perfect.

Some of the dangers to be overcome or avolded are: Lack of well directed propaganda; too much teacher direction; lack of respect for councilors; lack of capable leaders; lack of co-operation from the teachers; forming of cliques; and too much disciplinary power given to councilors.

The council has to be constantly on the lookout to see that its activities are well advertised by clearly defined propaganda directed toward the special goal in view. The machinery must be kept simple. The organized body must be kept within the bounds of opinion. Too often the mass of the student body does not conform in an intelligent manner; it is the duty of the council, therefore, to urge as many school groups as possible to co-operate with the organization so as to create more interest in and enthusiasm for their projects. The advisers have to keep themselves constently in the background, for they do not want "teacher directed" councils but "student directed" ones. In a group of 3000 there are alvays some persons who will not co-operate. For these it is necessary for the teachers to act as police. Nore educati on concerning the reasons and ideals of the student council 
is necessary; more advertising by the faculty is of the utmost importance.

The qualifications of candidates for office in the council must be carefully checked so as to secure real leaders capable of carrying out the policies of the council successiully. In the junior department the student Council work is relatively new to many of the faculty, and they fail sometimes to realize the importance of co-operation. The placing of certain responsibilities upon those teachers may create more interest in the work.

The tendency of the councilors to form a clique is sometimes seen but must be overcome. The councilors also have to be on their guard against creating in the minds of the pupils at large the opinion that the councilors feel their importance or superiority.

The placing of too mich disciplinary power in the hands of the councilors must be constantly avolded, for the students resent being dictated to, and the councilors sometimes will not report their fellow students.

The councilors, as we have seen, must be enthusiastic themselves about the project in order to sell the idea to the student body and faculty alike, so that it will succeed as nearly one hundred percent as possible.

In conclusion, we see that the values of student participation in Halleck Hall school government are two-fold: (I) it improves the general morale of the school and (2) it has a positive effect upon the pupil himself. There is less dis- 
ciplinary trouble; there is a changed attitude toward the school activities when the pupils are asked to take part in the government of school affairs. Even a changed attitude toward the class-room work is noticed. This participation in school government affords an excellent opportunity to develop school spirit, correlate "school" and "Iife," and crystalize school opinion. Finally, a satisfaction is created in the minds of the students when they are delegated authority.

Many of the disadvantages as well as the advantages attached to the movement seem ultimately connected with the psychological factors of personal likes and dislikes. Though the disadvantages are very real, they are also very human and are probably unavoidable in any activity involving a large number of persons. The situation is intensified at Halleck Hall by the fact that the two age groups are housed in the same building. Naturally, there is some intercourse, and each objects to the "authority" given representatives of the other. of more fundamental importance is the tendency for the movement to degenerate into a teacher-directed affair because of the lack of student interest. This can be overcome, as suggested in several comments only by intelligent propagandizing and sincere efforts to permit the students to assume maximum responsibility. 
B. Limitations and Problems in the Future

It is the writer's opinion that the weakest part of the Halleck Hall situation in regard to the student participation in school government is the junior high school student body. Lack of tradition and faliure to grasp the full implications of student participation are, it is felt, the chief defects at present. Efforts are now being made to do away with them as soon as possible.

Recently, an innovation has been made in the manner of electing the junior executive board members. Miss Edna Brown, adviser of the junior student council, explains the new plan of putting more democratic principles into the elections:

This term three members from each of the 7th, 8th, and $9 B$ sections must be nominated and one finally elected. Heretofore, the executive board eliminated and nominated, and the students voted by secret ballot in home-rooms.

The new plan for nomination and election is stated below:

1. About two weeks before election time (around the last of May), each class in each section is provided with questionnaires. (Halleck Hall has ability grouping; the refore, four or more questionnaires were distributed in the upper groups, two to midale groups, and one or none to the low or non-departmental groups.) Each teacher selects the students, who measure up to definite standards, to f1ll out the questionnaires. Each student who fills out a questi onnaire must obtain the signatures of at least four teachers. In order to be eligible the student mist:

a. Exemplify certain qualities of character such as honesty, dependability, self-control, intelligence, regularity, punctuality, common sense and good judgment, co-operation, clean and neat appearance, initiative, etc.

b. Have a " $B$ " average in all major subjects.

c. Have a clean record with the office.

d. Have time to serve and attend weekly joint meetings of the junior and senior executive boards, wedne sdays at 2:35 P.M. 
2. The student council adviser collects these questionnaires and checks them.

3. An elimination process then follows. This term there were too many names turned in. In order to eliminate fairly, in rooms where 4,6 , or 8 questionnaires were turned in, the class voted to support just two or three as the possible nominees from that class.

4. The adviser then sends to each home-room a list of names eligible for nomination.

5. The junior executive board then reserves the right to nominate one in each of the $7 \mathrm{~B}, 7 \mathrm{~A}, 8 \mathrm{~B}, 8 \mathrm{~A}$, and $9 \mathrm{~B}$ groups. Each group appears before the board. Each student in each group is then introduced and tells briefly what he will try to do for the school if he is elected. Three students in each group were nominated. The board by standing vote then elected one as a possible nominee.

6. Within the next day or so each of the five groups meets in the auditorium, separately. Each class is assigned certain seats together. The names of the possible nominees (usually five to nine) and their numbers are placed on the blackboard. These students are called out, introduced, and requested to say a few words. A brief talk on the importance of getting the right material for the board is then given by the adviser. Blank ballot slips are then distributed. Each student then wirites the names of any two eligibles. The student councilor and alternate in $\overline{e a c h}$ class collects, tabulates, and announces the names of the two receiving the most votes.

7. One week from the nominati on day each group meets again and elects by secret ballot one out of the three nominated the previous week.

8. The recreation committee elects two captains, one for each Iunch period; the traffic committee elects one captain; the School Boy Patrol elects one captain. These four boys represent their respective groups on the junior executive board. At present our junior board numbers nineteen.

9. After election the completed junior executive board chooses a chairman and also leaders for the various committees.

It is yet too early to say confidently whether the results justify the additional machinery; in Miss Brow's opinion, however, they do.

A step further in democratic procedure would be the election of the junior council chairman by secret ballot 
of the whole student body in a manner somewhat similar to that of the senior election. The junior council is only four years old, however, and the administrators feel that the junior students are immature and probably not capable of electing a good chairman. The writer hopes to see the full democratic procedure inaugurated in the near future.

Another activity to be considered in the future by the Student Council is the establishment of home-room guidance under student organization. The class should be fully organized with a president, vice-president, secretary-treasurer, and sergeant-at-arms. Various cormittees should be formed such as regularity and punctuality, hospitality, visitation of the sick, home assignments, citizenship, scholarship, co-operation, room beautification, bulletin boards, and special day programs. The class may be divided into two sides, the black and the gold (school colors), and compete for points. Points might be made for participation in school activities, in home-room programs, high scholarship rating, perfect regularity and punctuality. Demerits might be given for tardiness and absence without excuse, failure in scholarship, lack of co-operation, or poor citizenship, such as bad conduct in the home-room, or when reported by another teacher. A record would be carefully kept by the secretary, and honor given to the winning side. It is hoped that the children under such a plan will take part in a lively discussion of the rules of conduct in the home-room and want to formulate, even though they are very simple and crude, 
their own rules. Such a procedure will cause the students to be more loyal to their school and to be more willing to co-operate in obeying laws which they have formulated. This is a natural outcome of such democratic routine. One of the newest activities undertaken by the junior student council is the organization of a Suggestion Representative Committee. The chairman of the committee explains it thus:

The purpose of this committee is to make Halleck Hall a more democratic school by letting the students take a larger part in governing Halleck Hall. Each class should elect a representative who mist be trustworthy, intelligent, obedient to orders, regular in attendance to meetings, and have a good understanding of democracy. The representatives are supposed to get suggestions from their classes on what they want done in this school and bring them in to the meeting each week. Suggestions such as the following have been made: have soap and mirrors in the rest rooms, 80 to lockers during lunch period and free periods, etc. We have very good suggestions from the classes. These are discussed in the meeting, and if they are good and in reason, we take them to the principal. The representatives try to promote school spirit in the classes. We meet every Wednesday morning in the small cafeteria from 8:15 to 8:40. We have only been organized five weeks, and we hope to form an organization which will function for the good of the school.

Such a committee can be of great value in giving the students a larger voice in the government and will create greater interest and enthusiasm for student participation, which will be reflected in lasting results to the students. Only a start has been made, but the writer predicts that by next year an active organization will prove its worth in making many suggestions for the betterment of the AII Student Association and the student body at large. 
The junior and senior councils have been meeting together in joint session, but the juniors have decided that they want a separate meeting headed by their own chairman. The following article explains their stand very well:

Hore democracy for students! This is the slogan now used by the student council and executive board. We now have a representative government composed of fifty-one representatives from the home-rooms. But this does not satisfy some of our leaders. They want more democracy.

Elsie Lapp, member of the executive board, is the leader of the new movement. Her opinion is that the trouble is between the seniors and the juniors. The situation is similar to that of America and England when America was fighting for freedom from England. In our case the seniors have too much power over the juniors. The junior representatives and the senior representatives meet every Wednesday after school. A senior girl is president and the result is that the juniors keep too silent.

Elsie suggests that a remedy for this situation is to have the two boards meet separately and let each have its own president or chairmen to preside at the meetings. 1

Another project which deserves consideration is the getting out of a handbook for the junior students. The senior students have a handbook which serves very well, but its scope of usefulness could be increased by including more material explaining the various phases of the junior department.

Halleck Hi-Lights, May, 1938 。 
CHAPTER V

CONCLUSIONS AND SUMHARY 


\section{CHAPTER V \\ CONCLUSIONS AND SUMIARY}

A. Character of Holleck Hall Development in Comparison with General Movement

In a movement that has as many different forms of expression as that of student participation in school government, it is difficult to speak of general trends. Such studies as the one made by Ringsdahl state certain facts about the selected schools studied: for example, that the electoral unit in the majority of these schools is the class or the home-room, or that the supervision of extra-curricular activities is the duty of student councils most frequently mentioned. Acrain, there is some justification for the general statement that the home-room is the important focal point in the junior high school program, and that in the senior division the single-house type of student council is the one preferred. Since, however, each program has developed in response to the individual needs of the school, each is bound to e characterized by individual peculiarities, and though the needs to be satisfied may be generally similar, satisfactory solutions will be marked by local variations. It may perhaps be safely said that no part of the student participation program at Halleck Hall is unique; but, on the other hand, considered as a functioning whole, it is definitely individual.

Student participation in school government as it origina- 
ted at Louisville Girls' High School was, as we have seen, a gradual movement; the same unvillingness to plunge blindIy into such a program was evinced when the junior high school unit was created at the new school. Only after a term of careful study was the program finally instituted, and then by no means in a form that was considered final. Rugis stresses the gradual introduction of the movement as a characteristic of good student participation programs throughout the country.

A second characteristic mentioned by him is that the machinery of government with which the students work is kept as simple as possible. In the writer's opinion, simplicity does characterize the Helleck Hall set-up. Beginning with the popular, home-room, direct election of councilors to the election of executive board members each process can be easily understood by every participant and the functions observed.

The writer is convinced that the majority of students and faculty at Halleck Hall does favor student participation. Certainly it is a co-operative undertaking which covid not function without the support of the majority of both, and such co-operation is, therefore, characteristic of all vital student participation programs.

It is of the utmost importance that as many of the student body participate, and do so consciously, in the governmental activities as posible. The reason for this is obvious, 
and it is also plain that this is one of the most difficult requirements for a program to fulfill. At election time, of course, the students are very much aware of their share in the government, and to those elected to some office this awareness is constantly present. To the greater number, however, their responsibility and share in the operation of the school would become a matter of indifference. At Halleck Hall, a full and varied prozram of campaigns for the improvement of various aspects of the school life is carried on to maintain all-student interest.

\section{B. Present Status of the Program}

The question of whether or not to have student participation in school government does not enter into calculations for the future school program. Long ago student participation in school government at Halleck Hall became a fixed procedure in school practices, for the worth of it as a democratic principle of government has been proved.

The adrinistrators are positively convinced that while student government is not necessary to the actual running of the school itself, the student body are so benefited by the active participation in worthwhile projects for the best interests of the school that ever to eliminate student participation would be a backward step in progressive school procedures. The administrators are fully aware that this modern school must adapt itself to a new social order so as 
to meet the needs of a society which is in process of social reconstruction thereby training "citizens of tomorrow."

Never before in the history of education have the schools been brought so clearly face to face with the needs of training for better citizenship and of fostering the ideals of democracy. Student government is one of the most effectual means by which students can get this training. One of the recommendations for future enlargement of the All student Association, therefore, is to seek in every possible way "to sive the individual an adequate knowledge of the complex social problems involved in the effective group relationships, and training and meeting successfully the responsibilities in a constantly changing social worla."

One may say that the Halleck Hall student government proGram has had that objective for some years past, but still it bears repetition, for one must never lose sight of this strongest recommendation for the creation of student covernment and must always be on the lookout for all possible avenues of approach toward the realizetion of that objective.

We have tried to present a picture of the governmental set-up as it functions in Halleck Hall today. It is easily seen that adverse criticism is not absent, although the

\footnotetext{
1 L. McNulty and E. Bolton, "Student Government in Junior and Senior High School," The High School Quarterly, 24:165-70 (April, 1936)
} 
writer feels that a great number of students and faculty are in favor of the plan. It is significant, she believes, that those teachers who have most opportunity to come into close contact with the various agencies of the student government enthusiastically support it.

Lewis says: "The only sound reason for student part1 cipation is the development of social attitudes and skills appropriate to citizens in a democracy rather than the docile and long suffering obedience appropriate to subjects of despotism."I It is, therefore, the business of the All Student Association to evaluate more carefully its future activities in the light of such a purpose.

\section{Suggestions for Future work}

An excellent way to make student government a vital part of the life of the student would be to organize a class in student government. Such a class has been in process of development within the past few years in the Sacremento Senior High School. Its history and accomplishments were reported by Laws on and Murphy in an article published in the California Journal of Secondary Education.2

Such a class in student government is possible for

1 William D. Lewis, op. cit., pp. 416-

2 M. F. Lawson and M. P.Murphy, "A Class in Student Body Government," Calif ornia Journal of Secondary Education, 
Halleck Hall. The ma in purposes of the project as listed are equally applicable to the situation at our school. The organization of such a class would be "unique" Indeed, but its organization would flll a felt need in solving some of the complex problems found in the student government of the school. This would be another method of enlarging the scope of the All Student Association at Halleck Hall, and it is strongly recommended by the writer as a cure for many socalled "ills" of student government.

Another activity very worthy of consideration is the "point system" of awards for school activities. Robert P. Wray recommends it as a student council project.

If a school has a student council organization, the work connected with the devising of the "point system" should certainly be its business... object: to develop leadership and stimulate interest in the activities of the school... and to establish and administer a "point system" of awards for meritorious participation in student activities.

The entire administration of the system is, of course, in the hands of the council. The president is directly responsible and is assisted by a spocial committee each term. A cumulative record is kept of the activities of each student from the time he enters the school. These cumlative records are under the general care of the council and the direct care of the home-room representatives. The essential characteristic of a "point system" is that each activity under consideration be rated according to a certain number of points for meritorious participation in it. (For example, membership with the student council carries three points and the presidency twelve points.) Certain insignia are awarded with in four weeks of the end of the school term.

Another plan to widen the scope of the All Student Associa-

I R. P. Wray, "A Point System of Awards for School Activities," Junior and Senior High School Clearing House, 9:428-3I Miarch, 1935) 
tion is the following: the senior adviser of the Association has been anxious for several years past to have the student council sponsor a financlal plan under a general treasurer who would handle all funds of the student organizations. This treasurer would have charge of all monies made and the sale of tickets to events sponsored by the school. A tremendous amount of bookkeepins would be involved, but the plan has been working satisfactorily in numerous high schools throughout the country, and no doubt if careful consideration were given it at Halleck Hall, it could be inaugurated and serve a felt need in the school. Possibly in the future the plan will be tried out; at present, it is merely a sugestion. In such a large school as Halleck Hall it is often very difficult to get the whole-hearted co-operation of the faculty and the student body. One criticism has been justly made of Iraleck Irall -- that of the lack of proper school spirit. A special booster chairman with a selected committee of interested students should be formed. This chairman should be a teecher who is especially fitted for that type of booster rork and wllling to put enthusiasm into all worthy projects. The duty of the committee would be to put on a Better Attendance Drive, to reduce tardiness, to boost school plays, etc. An assembly given over to proper recognition of winning classes with school yells, songs, and speeches will tend to create Halleck Hall spirit. 
The enlargement of the scope of student participation through the medium of the All student Association, briefly suggested here, is outlined in the hope that Halleck Hall may become, to the fullest extent, "a place where one grows in knowledge, in loyal co-operation, in loving comradeship, in honest endeavor, in gracious courtesy," and truly "its colors may fly over a school of ever widening influences and deepening purposes." 


\section{APPENDIX}


CONSTIMUPION OF THE STUDENS ORGANIZATION OF HALLECK HALL

\section{ART ICLE I \\ SECT ION - 1--NAPE}

This organization shall be called the All Student Association of Halleck Hall.

\section{SECTION 2---PURPOSE}

Its purpose shall be to secure the co-operation of the entire body in matters of conduct and discipline, in order that the faculty may not have to deal with these questions outside of the classroom itself. Its aim is also to foster a spirt of school loyalty and pride.

\section{SECIION 3---MEMBERSH IP}

AIl students of the Louisville Girls' High School and the Loulsville Junior High School sha 11 be members of this organization.

\section{SECTION 4---GOVERNWENT}

This Association shall have a governing body called the Student Council whose work shall be directed by a senior and Junior Executive Board.

\section{ART ICLE II}

\section{SECT ION 1---MEMRERSH IP}

Each Home Room shall elect one representative to serve on the council, also an alternate to serve in the absence of the representative.

\section{SECIION 2---ELECI ION}

Elections of Student Councilors to represent Home Rooms shall take place the first of each term, the specific date to be fixed by the Executive Board each term.

\section{SECTION 3---REQUIREMENTS}

Nembers are elected for one term and are eligible for reelection. They must have had a grade of 80 and no failures for the preceding term and must meet with the approval of the faculty adviser in charge of the group (the teacher of the Home Room). They must mainta in the required average. 
SECIION 4--NEETINGS OF THE STUDENT COUNCIL

The student Council shall meet once each week at a time agreed upon at the beginnine of each term. Each member shall be E.llowed two unexcused absences. Upon a third unexcused absence the member shall be automatically dropped, and the Home Room shall be advised to elect a new representative.

\section{SECI ION 5---OFFICERS}

The officers shall be a President and a Vice-President, a Secretary and a Treasurer.

\section{SECT ION 6---ELECT ION OF THE OFT ICERS}

The President and Vice-President shall serve for one year. They shell be nominated in December at a conventi on composed of the Council and Alternate from each Senior Home Room. The nominees mast have served on the Executive Board of the Student Council at least one term and must be members of the English IV, V, VI classes. They shall be voted on by the senior school at large, in Jenuary, after a regular canpaign. The Secretary and the Treasurer shall be elected by the secret ballot of the Executive Board and shall perform the duties of their offices for both bodies.

\section{SECTION 7--OINSTALLATION}

The President and Vice-Fresident and the members of the Council shall be installed at a Chapel period set aside for that purpose.

\section{OATH OF OFFICE}

The Principal shall administer the following oath of of ice to the President and Vice-President: "I do solemnly promise that I will uphold the ideals of the Louisville Girls High School and will faithfully discherge, to the best of my ability, the duties of the high office on which I am about to enter." The President shall administer the following oath to the members of the Council:

"I promise to do my duty as a member of the student Council of the Louisville Girls High School or Loulsville Junior High School." The President shall administer the oath of office to the Alternates.

The Principal shall call on the school for a pledge of loyalty as follows:

"As a member of the Student Organization of the Louisville Girls High School or the Louisville Junior High School, I pledge my loyal support to the Student Council of the School." 


\section{SECIION-8- -DUTIES OF PRESIDENT AND VICE-PRES IDENT}

The President shall preside at all meetings of the All Student Association and of the Student Council. She shall have the power to call extra sessions of the council, if necessary. In her absence, her duties shall be performed by the vice-President.

\section{SECTION 9---DutieS OF STUDENI COUNCII IEMBERS}

The members of the student Council must perform a 11 duties that they are directed by the Executive Board to perform. Any Councilor not performing duties faithfully and efficientIy may be dropped by the action of the Executive Board. Fach member shall see that a business meeting is held in the Home Room on an appointed day after the student Council meeting and that matters of interest to the school are discussed. The Councilor shall present the opinions and suggestions of the class to the student council meetings and bring back to the class the decisions of the council. The councilor must wear the badge every day, all day. Badge - Student Councilors shall wear a gold shield-shaped badge with a black S.C. on it.

\section{SECIION 10---WIETINGS IN SECIIONS}

The Student Council member shall preside over the meetings of one division of the AII Student Association which is the Home Room class of the Councilor. The Alternate shall be the secretary of the meeting which shall be conducted according to Robert's Rules of Order. The teacher of the Home Room shall act as sponsor.

\section{Alternates}

Alternates must perform the Home Roon duties of the student Councilors when they are absent. An Alternate mast act as secretary for the meetings of that section of the All student Association. The Alterna te must wear the badge daily and perform any duties that are assigned by the Executive Board. Badge---Alternates shall wear a gold, shield-shaped badge with a black $A$ on it.

\section{SECTION 1I---GOVERNING BOARD}

There shall be a governing board of the Student Council called the Executive Board of the Student Council. 


\section{ART ICLE III}

EXECUTIVE BOAPD OF THE STUDENT COUNCIL

\section{SECTION 1---OFFICEKS}

The officers shall be a Chairman, Vice-Chairman, Secretary, and Treasurer. The Chairman of the Senior group shall be elected from the English VI class in June and shall hold the office during the entire year following. The other officers may be elected from members of the Junior or Senior Classes and shall be nominated and elected by the secret ballot of the Executive Board. The Junior Chairman shall be elected at the same time by the Junior Executive Board from the 8th or 9 th grade members and shall hold office for one year. The Vice-Chairman, Secretary and Treasurer mist be elected from the same grades and serve for one year.

\section{SECTION 2-- -IE MBEPSH IP}

The Executive Board of the Senfor Council after the June election shall consist of not more than 18 or fewer than 15 members as follows: 3 English VIII, 3 English VII, 3 English VI, 3 English V, 3 English IV, and 2 English III, 1 artist. Vacancies occurring during the year shall be filled by the members elected by the English classes.

\section{Junior}

The Executive Board of the Junior Council after the June election shall consist of $39 \mathrm{~A}, 39 \mathrm{~B}, 38 \mathrm{~A}, 17 \mathrm{~A}$, and $\mathrm{a}$ representative of the School Boy Patrol.

\section{SECTI ON 3---NOMINAT ING BOARD}

Members of the Executive Board of the Student Council shall be nominated by members of the class which they are to represent, the nominations to take place after the class has been duly notified. Each student in the class shall be permitted one nonination.

The following form of ballot shall be used: Name of Nominee Signed

(Name of person making nominations).

\section{ELECTION OF BOARD}

The three students (or two in a small class) receiving the highest number of votes shall be voted upon by secret ballot in a class meeting called for that purpose, in school time, with in one week after the nominations have been made. Junior - The Junior Students shall vote in their own Home Rooms . 


\section{REQUIREMENT}

All candidates for membership on the board mast have a general grade of 80 or more for the preceding term, no falling marks, and a satisfactory conduct record, and must maintain these standards or be automatically dropped.

\section{IENGTH OF SERVICE}

Nembers of the Board shall serve as long as they render service that meets with the approval of the Faculty and the Executive Board.

They shall take the following oath:

"I promise to do my duty as a member of the Executive Board of the Student Council of the Loulsville Girls High School (or Louisville Junior High School)."

\section{BADGE}

The Board members shall wear a black, shield-shaped badge with a gold $S$. C. on it.

\section{SECTION 4--DUT IES OF THE OEHICERS}

The Chairman shall preside at all meetings and direct all the activities of the Board, and shall have the power to call special meetings, if necessary. The Chaiman shall take the following oath:

"I do solemnly promise that I will uphold the ideals of the Louisville Girls High School, or Louisville Junior High School, and will faithfully discharge to the best of my ability, the duties of the high office on which I am about to enter."

\section{SECT ION 5--- VICE-CHAIRMAN}

The Vice-Chairman shall perform the duties of the Chairman when the Chairmm is absent ănd assist in a 11 possible ways when the Chairman is present.

"I do solemnly promise that I will uphold the ideals of the Louisville Girls High School or the Louisville Junior High School, and will faithfully discharge to the best of my ability, the duties of the high office on which I am about to enter."

\section{SECTION 6---SECRET ARY}

The Secretary shall call the roll and write the minutes of all meetings of the Board and of the council and attend to all correspondence. 


\section{SECTION 7-OTREASURER}

The Treasurer shall have charge of all the funds and shall attend to all financial matters connected with the council.

\section{SECT ION 8---COMITTEES}

Nembers of the Executive Board shall act as chairman of comittees of the Student Council. Such chairmen are to be appointed by the Chairman of the Executive Board at the beginning of each term. They are to form their own committees of Student Councilors and Alternates who are to perform any duties that are required. The committees shall be the following: Traffic, Iunchroom, House, Assembly, (care of building), Propaganda, Badge, Library, Campus, Gym., and any other necessary committee.

\section{SECIION 9---ADVISERS}

There shall be three or nore members of the Senior Faculty (and three of the Junior Faculty) who shall act in an advisory capacity to the Executive Board.

\section{SECT ION 10 - NEEET INGS}

The meetings of the Executive Board shall be held at least once a week at stated times, agreed upon by the members at the beginning of the school term. The chairman may call extra meetings whenever necessary.

\section{ABSENCE}

Each member of the Board shall be allowed two unexcused absences from the council meeting during a term. Upon a" third absence, the member shall be antomatical ly dropped.

\section{SECTION II--2UORUM}

A quorum shall consist of one Faculty adviser and ten members of the Board.

\section{SECT ION 12---FULES OF ORDER}

"Robert's Rules of Order" shall be used as authority in parliamentary law.

\section{SECTION 13---AUT HORITY}

The Executive Board shall have the right to try all cases of disorder occurring under the jurisdiction of the council and pass sentence thereon. 


\section{SECT ION 14---AIIENDMENT}

This Constitution may be amended by a majority vote of the Faculty and by a unanimous vote of the Executive Board of the council.

\section{Amendment I}

The Executive Board, if it deems wise, shall appoint an artist who will be an honorary member of the Board.

Such artist must be recomrnended by the art instructor and must meet the requirements demanded of the regular Board liembers.

She shall serve for one term and be eligible for re-election.

She shall be known as the S. C. Artist and wear a special badge, a black shield on a gold shield with gold S.C.

The only duty required of the Artist shall be to plan and execute all the art work needed in carrying out the plan of the Propaganda Committee of the Board.

The Artist shall become a member of the $\mathrm{S}$. C. Ixecutive Board Home Room.

She shall attend all Board and Student Councli meetings, but shall have no vote.

She shall take the following oath:

"I promise to do my duty as the Artist of the student Council of the Louisville Girls Hikh School (and the Louisville Junior High School)." 
QUESTIONNAIFE FOR PROSPECIVE CANDIDATES FOR EXECUTIVE BOARD OF SIUDENT COUNCIL

Grade __ Name $\quad \begin{aligned} & \text { Noom } \\ & \text { Home }\end{aligned}$

Possible Candidate for the Executive Board of the Student Council

1. Are you interested in serving your school?

2. Could you afford to devote some of your time to Student Council work?

3. What is your average in each subject this year?

4. Have you had any failing marks on your report this term or last?

5. How many times have you been corrected by the office for misconduct in Halleck Hall?

6. How many times have you been tardy this term?

7. How many times have you been absent this term?

8. Do you remember to obey the traffic laws in the halls?

9. Do you obey the cafeteria rules?

10. Do you feel that you would like to work on the S. C. to make Halleck Hall a pleasant place to live?

11. Check in the following list the qualities you possess that a student councilor should possess:

Ability to get alone with others

Honesty

Punctuality

Trustworthiness

Self-control under trying circumstances

Courtesy

Obedience

Ability to follow directions

Good Judgment

Neat appearan ce

Consideration for school property

Good health

12. What qualities do you possess that a Student Councilor should not possess?

Your name

Have your teachers sign efficient Student councilor. would make a trustworthy, 
Catechism of Halleck Hall's Junior Student Government

I. Q. What is student government?

A. Student govermment is the cooperation of the pupils in their attempt to make Halleck Fiall the best of schools.

2. Q: Who controls student government at Halleck Fall?

A: The All Student Association of Halleck Hall.

3. Q. What is the All Student Association of Halleck Hall?

A. An organization which includes all citizens (pupils) of Halleck Fiall.

4. Q. Iow does this Association work?

A. Through the Student Council and the Junior and Senior Executive Boards.

5. Q. What is the Student Council?

A. A group of pupils made up of one representative and one alternate from each home-room.

6. Q6 What does the Student Council do?

A. It discusses and plans things which can be done for the good of our school.

7. Q: When does the Student Council meet?

A. Every Thursday during Home Room period in $\mathrm{R}$. 2II.

8. Q. What is the Junior Executive Board?

A. A small group of 15 citizens (pupils) elected by grades yearly, to help plan the vork of the student Council. Two of these fifteen represent the School Boy Patrol and the Traffic Council.

9. Q. What is the representative from each Home Room to the Student Council called?

A: A student Councilor.

10. $Q$ : Who can be a Student Councilor?

A. Any $p$ upil who has an average grade of 80 and who is regular and punctual in attendance, who has a clean record in the office, certain qualities of character, no failures for the preceding term, and who otherwise meets with the approval of the Home Room teacher.

11. Q. How does a Student Councilor get his office?

A. He is elected by his Home Room class.

12. Q. For how long does a student Councilor hold office?

A: For one term unless renoved.

13. Q. For what can a Student councilor be removed?

A. For three unexcused absences, from Council lineetings. Because of his failure to keep his grade up to 80 . Because of bad citizienship, upon the recommendation of a faculty member.

14. Q: What kind of person should a Student Councilor be? A. He should be honest, punctual, courteous, and in good health, cooperative, trustworthy, obedient, neat and considerate.

15. Q: Who is the ma in officer in the Junior Student Council? A. The Chairman, J.E. Turner. 
16. Q. Who can be Chairman?

A. A boy from the 8 th or 9 th grade group who meets the requirements.

17. Q: What are those requirements?

A. The same as those required for a Home Room representative, plus evidences of initiative and leadership. He must have been on the Executive Board.

18. Q. What are the main duties of the Chairman?

A. To preside at all meetings of the Student Counc1l.

19. Q. Who takes the Chairman's place if for any reason he cannot perform his duties?

A. The Vice-Chairman.

20. Q: Who can be Vice-Chairman?

A. Any student who can meet the requirement for Chairman.

21. Q. How long do the Chairman and the Vice-Chairman hold office?

A. For one year.

22. Q. How do the Chairman and Vice-Chairman get their offices?

- A: They are elected by the pupils of the junior division.

23. Q. What other general officers does the student Council have?

A. A secretary and a treasurer.

24. Q: How do they get their offices?

A. They are elected by the secret ballot of the Executive Board.

25. Q. What is the duty of a Student Councilor?

A. To be the representative of his Home Room and to take care of any duties assigned him by the Executive Board.

26. Q. What kind of badge does a Student Councilor wear?

A: A gold shield-shaped badge with a black S.C. on it.

27. Q: Should the Student Councilor wear his badge?

A. He should wear it every day all day.

28. Q. What is an Alternate?

A. A pupil who takes the place of a Student Councilor When the Student Councilor is absent.

29. Q. Does the Alternate have any other duties?

A. He mast wear his badge daily and perform any duties assigned by the Executive Board.

30. Q: What kind of badge does the Alternate wear?

A. A gold shield-shaped badge with a black A. on it.

31. Q. How many members are there on the Junior Executive Board?

A: Fifteen.

32. Q. How do they get their of fices?

A. Most of them are elected by classes.

33. Q. How are they divided among the classes?

A. Three from 9A, three from 9B, three from 8A, three from $8 B$, one from $7 \mathrm{~A}$, and the captains of the Traffic Council and the School Boy Patrol. 
34. Q. How are candidates for the Junior Executive Board elected?

A: By ballot in the various Home Rooms.

35. Q. What is the main duty of the Executive Board members?

A. To serve as chairmen of the following committees: School Boy Patrol, Traffic, Lunchroom, Health and House, Assembly, Publicity or Propaganda, Badge, Library, Campus and Gymna sium, Press and other necessary committees. To plan the work which is discussed. and voted upon by the student Council which meets egch Thursday following the second hour in the large cafeteria on the second floor.

36. Q. How often do the junior and senior Executive Boards meet?

A. Once a week on Wednesday in Room 337, from 2:35-3:00 P.M. 
JUNIOR DIVISION'S TEST ON THE STUDENT COUNCIL CONST ITUIION

I. Matching - The first column is numbered from 1 to 10; the second from a to $j$. Copy down the numbers from 1 to 10 and beside each place the letter in Column 2 which corresponds to it.

1. Home Room Teacher

2. Wednesday $2: 30-300, R \cdot 337$

3. S. C. and Alternate

4. Chairman of Executive Board

5. All Student Association of Halleck Hall

6. Executive Board members

7. Thur sdxy, 8:15-8:45, R. 212

8. Gold S. C. with gold with "T" on black shield

9. Student Council

10. Black "T" with 2 chevrons on Eold shield. a. Meets Monday in Home Rooms 8:33-8:50

b. Helps to carry out the work planned by the Executive Board.

c. Traffic Captain's badge.

a. Badge of lst Iieutenant of Junior Traffic Council

e. Time and place of Junior Student Council meeting

f. Adviser and his S.C. and Alternate

g. Representatives of a Hom Room.

h. Elected in the Junior Division by sections.

1. Elected by the Executive Board and serves one year

j. Junior and Senior Executive Boards meet

II. Complete:

1. Our present plan of Student Government was adopted years ago.

2. The Chairman of the Junfor Executive Board is elected by the

3. Student Councilors and Alternates are elected by their

4. Three requirements for the Student Councilor or Alternate Are: a) b) c)

5. The Junior Student Council meets weekIy on from to in room morning

6. The Executive Board member who presides is named

7. The governing board is called an

8. The name of our student organization is

9. This organization conducts a meeting on from to in each

10. At this me ting the presides.

11. The Executive Board functions by means of the following committees (name at least six):

a)

d) , b) 
II. ( c on).

12. Each Home Room Teacher acts as an to his S. C. and Alternate.

13. Student Government is

14. The Student Council does the following:

III. Briefly describe any six of the following badges:

1. Traffic Captain's

2. Student Councilor's

3. First Lieutenant's of Traffic

4. Alternate's

5. Junior Executive Board Member's

6. Patrolman's

7. School Boy Patrolman's

8. Second Ileutenant's of Traffic

IV. Multiple Choice - Check the correct answer.

1. The Junior Executive Board is made up of $(12,20,15)$ members.

2. The Chairman of the Junior Executive Board is elected by the (Executive Board, the Student Council, the All-Student Association)for ( 1 year, 5 months, 2 years).

3. Nembers of the Junior Board serve ( 1 year, one term, remaining terms of school life in Halleck Hall.)

4. The purpose of Student Govermment is to (keep order in class-rooms, foster a loyal cooperative spirit among students).

5. Our government is (Student Council Government, Student Government).

6. Student Councilors and Alternates serve ( $I$ year, one term, 2 years).

7. The care of the building is especially sponsored by the (Badge Committee, Inspection Committee, Cafeteria Committee). 
SENIOR DIVISION'S TEST ON WHE SHUDENT COUNCIL CONSTITUIICN

Check correct statement:

1. Our Government is (1. Student Council Government) or (2. Student Government).

2. Each member votes for (1. All the Board Members) or (2. One Student Councilor.)

3. (1) All the Student Councilors of Halleck Hall meet together.

(2) The Junior and Senior Executive Boards meet together.

4. The purpose of student government is to (1. to keep order in the classrooms), (2. to foster a loyal cooperative spirit among the students).

5. inembers of the Board serve (I. one year), (2. one term), (3. remaining terms of school life).

True-False: Check True Statements:

1. Our present plan of student government was adopted 20 years ago.

2. Some students do not have a right to vote.

3. The home room teacher is the adviser to the S. C. and Alternate of her home room.

4. There is no connection between the Senior and Junior Student Council in Halleck Hall.

5. The President is elected by the Executive Board.

\section{Completion:}

1. Student Government was instituted in L.G.H.S. in the year

2. The present ${ }^{\circ}$ constitution was written in and revised in

3. The name of our student organization is

4. The governing board is called

5. The membership of our governing board consists of

6. It functions by means of the following committees:

7. Hembers of the board obtain their of fices by

8. All have a right to vote.

9. Student Councilors and Alternates are elected by:

10. The requirements are 


\section{APPLICATION CARD - - HALLECK HALL TRAFFIC COUNCIL}

Last Name First Name

Home Room Teacher Grade Room

Applicant's Home Address

Height Weight Age

Non.

Tues.

Wed. I hereby consent to having

Thurs. my son serve as a member

Fri. of the Traffic Councif

Sicnature of Parent (Guardian) DO NOT WEITE BELOW THIS LINE

Assigned to Squad No. Received Equipment

(Reverse side of card)

PLEDGE

I promise that I will conscientiously perform my duty as a member of the Traffic Patrol of the Louisville Junfor High School.

TRAPFIC RULES

Never attempt to perform any duty unless you are vearing your badge.

PAPROL $D E N$

1. Walk through hall.

2: Be sjlent in hall.

- 3. Leave class exactiy 2 minutes before bell.

4. Know time schedule daily.

5. Know Traffic regulations.

6. Look neat and clean always.

7. Stand in an official manner, Nor an officious manner.

8. Be courteous always.

9. Never touch a siri.

10. Avoid putting your hands on your fellow students as much es possible 
11: Never lose your temper.

12: Be punctual and regular.

13: The officers ims have complete cooperation.

14. The Traffio Council is made from the better class of boys and others will look to you as their example. Always be above reproach.

I HAVE THOFOUGHLY READ THE ABOVE INEORIATION, AND UPON INY HONOR, PIEDGE IYSELF TO ABIDE BY SAME,

Pledged by 
QUESTONNAIRE ON PUFII ACTIVITY FOR SUPVEY OF CO-OP HRATIVE SIUDY OF SECONDGRY SCEOOL STANDARDS

Instructions for answering questionnaire:

Check lists: The use of the various check lists requires three symbols:

+ : conditions or provisions are made to a satisfactory degree.

- : conditions are not present or made to a satisfactory degree.

0 : conditions or provisions do not apply.

Evaluations:

4: perfect or practically perfect; the conditions or provisions are present and functioning perfectly or almost perfectly.

3: very good; distinctly above average; the conditions or provisions are present and functioning very well.

2: average; the conditions or provisions are present and functioning fairly well.

1: poor; distinctly below average; the conditions or provisions inadequate or, if present, are functioning poorly.

o: very poor; the conditions or provisions, although needed, are not present at all. 
PUPIL PART ICIPATION IN SCHOOL GOVERNIENT

CHECK IIST :

(+) 1. The school government is primarily concerned with the development of school leadership and service that will enlist pupils in the support of the health, thrift, beautification, recreational, and instructional programs and in the various phases of the pupil activity program.

$(+)$ H2. Authority for pupil participation in school sovernment is granted by the faculty through the principal to the pupil body or any unit thereof, the bounds and limitations of the new authority granted being clearly indicated in a vritten statement. This statement also provides that authority granted may be revoked.

$(+)$ 3. The government of the school is democratic and cooperative; every pupil has a responsibility for proper conduct and for the functioning of the government.

(t) 4. All campaigns, elections, and counting of ballots are carefully supervised.

(+) 5. Provision is made for directing traffic, promoting safety, and protecting property.

(t) 6. The development of socially desirable attitudes is sought.

Addenda:* There is no statement conceming revocation of authority granted, but students understand that the authorities reserve the right to revoke authority when the privilege is abused.

EVALUAT IORS:

(4)* y. How extensive is the responsibility of pupils for their own proper conduct?

(3) z. How well do the pupils accept their responsibilities as indicated by what the y actually do?

* The junior evaluation for this item is 3 instead of 4 . HONE-ROOMS---IN ADDITION TO IIERS SPECIFIED ABOVE

CHECK LIST :

(t) 1. Administrative functions assigned to home rooms are made a means of learning how to as sume and discharge responsibilities effectively.

(t) 2. Home rooms have a definite place and share in stimulating and developing a desirable school morale, this reducing disciplinary difficulties 
$2(\operatorname{con})$.

and having a corrective influence on those who have offended. (This does not mean that pupils are made responsible for disciplinary cases.)

(t) 3. Home rooms afford and encourage opportunity for full discussion and evaluation of various school conditions and problems and seek their improvement or correction.

(t) 4. Home rooms encourage self-expression on the part of al 1 their members to the end that creative abilities may be discovered and encouraged.

(t) 5. In the home room; every member contributed to its activities and shares in its responsibilities.

(t) 6. Time is provided in the weekly schedule for at least one class period (or the equivalent) for group discussion or conference.

EVALUATION:

( 3 )y. How adequately are provisions made for homeroom functions or activities?

( 3)z. How effectively are conditions or results such as the above attained?

COMIENTS:

Insufficient time is allowed. The number of classrooms is inadequate. 
GENERAL SUMMARY OF THE PUPIL ACTIVITY PROGRAM (SENIOR SECTION)

1. What are the best elements or characteristics of the pupil activity program?

a. Opportunity for pupil development.

b. Appeals to a variety of interests.

c. Democratic organization.

2. In what respect is it least adequate or in greatest need of improvement?

a. Does not provide opportunity enough for tenth grade pupils.

b. Lack of suitable meeting places.

3. What improvements are now being made or are planned for the immediate future?

a. Parliamentary law for class officers.

4. What studies has the school made in this field since September, 1934, or is it now making?

a. Continuous study to improve student government.

GENERAL SUMMARY OF THE PUPIL ACTIVITY PKOGRAM (JUNIOR SECTION)

1. What are the best elements or characteristics of the pupil activity program?

a. Provision is made for all to participate.

b. Diversified program.

c. Opportunity to develop leadership.

2. In what respect is it least adequate or in greatest need of improvement?

a. School publications.

b. Financing plan.

c. Lack of "Halleck Hall" spirit.

3. What improvements are now being made or are planned for the inmediate future?

a. Student handbook.

4. That studies has the school made in this field since September, 1934, or is it now mak ing?

a. Continuous study to improve student government. 


\section{BIBLIOGRAPHY}

\section{Books}

Allen, Charles F., Alexander, Thomas, and Means, Hendree, Extra Curricular Activities in the Elementary Schools, st. Iouis, Western Publishing compañy, $193 \%$

Brewer, John M., and others, Cases in the Administration of Guidance, New York, McGraw-HIII Book Company, 1929. -

Briggs, T. H., The Junior High School, Chapter I, HoughtonMiffin, 1917.

Cook, H. Caldwell, The Play Way, New York, Frederick A. Stokes Company, I919.

Cox, Philip W. I., and Iangfitt, R. Emerson, High School Administration and Supervision, New York, Americal Book Company, 1934.

Cox, Philip W. I., Creative School Control, Chicago, J. B. Lippincott Company, 192\%.

Cronson, Bernard, Pup1l Self Government, New York, The Macmilian Compan $\overline{\mathrm{y}, 190 \% . ~}$

Cubberley, E. P., The Principal and His School, Chicago, Hought on-Miffin Company, 1923.

Davis, C. 0., Junior High School Education, New York, Yonkers-on-the-Hudson, WorId Book Company, 1924.

Dewey, John, Moral Principles in Education, Chicago, HoughtonMifflin Company, 1909.

Dewey, John, The School and Society, Chapter I, University of Chicago Press, 19I5.

Douglass, Harl R., Organization and Administration of Secondary Schools, New York, Ginn and Company, 1932.

Douglass, Harl R., Secondary Education for Youth in Modern America, Washington, D. C., Americ councli on Equcation, 1937.

Edmonson, James $B_{.}$, Roemer, Joseph, and Bacon, Francis I., Secondary School Administration, New York, The Macmilian Company, 1932 . 
Books (con)

Fletcher, John M., Psychology in Education, Garden City, New York, Doubleday, Doran and Company, 1934.

Foster, C. W., Extra Curricular Activities in High Schools, Richmond, $\sqrt{a \cdot,}$ Johns on Publishing Company, 1925.

Fourteenth Yearbook, The National Elementary Principals Bulletin of the Department of Elementary School

Principals, National Education Association, Washington, D. C., 1935.

Fretwell, Elbert K., Extra Curricular Activities in Secondary Schools, New York, Hought on-Miffin Company, I93I.

George, William, The Junior Republic, Its History and Ideals, New York, D. Appleton and Company, I910.

Good, Iris C., and Crow, Jane M., Home Room Activities, New York, Professional and Technical Press, 1930.

Heaton, Kenneth Lewis, The Character Emphasis in Education, Chicago, The University of Chicago Press, I933.

Johnson, C. H., Newlon, J. H., and Peckwell, F. C., Junior-Senior High School Administration, New York, Charles Scribners, 1922.

Kilpatrick, William H., Education for a Changing Civilization, New York, The Century Company, I931.

Kilpatrick, William H., Our Educational Task, Chapel Hill, University of North Carolina Press, 1930.

Kilpatrick, William $\mathrm{H}$., and others, The Educational Frontier, Nev York, The Century Company, 1933.

King, Irving, Social Aspects of Education, New York, The Macmilian Company, I9I2.

Koos, Leonard V., Analysis of the General Iiterature on Extra Curricular Activities," Twenty-fifth Yearbook, National society for the Study of Education, Bloomington, Illinois, Public School Publishing Compeny, 1926.

Koos, Leonard V., The Junior High School, Columbus, Ohio, Ginn and Company, 1926 . 
Books (con)

Lewis, Wlliam Dodge, "The School as a Democratic Institution," Fourteenth Yearbook, The Department of Elementary School Principals, National Education Association, 1935.

McCloskey, A. Katherine, "Building Character by Pupil Participation," Fourteenth Yearbook, The Department of Elementary School Principals, National Education Association, 1935.

If Kown, Harry C., Extra Curricular Activities, Chapter IV, New York, The Macmilian Company, 193\%.

McKown, Harry C., Home Room Guidance, New York, McGraw-Hill Book Company, 1934 .

Meyer, Harold D., A Handbook of Extra Curricular Activities in the High Schools, New York, A.S. Barnes and Company, 1927.

Proctor, William M., and Ricciardi, Nicholvs, The Junior High School, Stanford, California, Stanford University Press, 1930.

Roberts, Alex C., and Draper, Edgar H., Extra Class and IntraKural Activities in High Schools, New York, D. C. Heath and Company, 1928 .

Roemer, Joseph and Allen, Charles F., Readings in Extra Curricular Activities, Richmond, Va., Johnson Publishing Company, I929.

Roberts, Alex. C., and Draper, Edgar M., The High School Principal as Administrator, New York, D. C. Heath and Company, 1927 .

Roemer, Joseph, and Allen, Charles F., Extra Curricular Activities in Junior and Senior H1gh Schools, New York, D. C. Heath and Company, 1926.

Rugg, Errle, "Student Participation in School Government," Twenty-fifth Yearbook, National Soclety for the Study of Education, Bloomington, Illinois, Public School Publishing Company, 1926.

Rugg, Earle, Summary of Investigation Relating to Extra Curricular Activities, Greely, colorado, Colorado State Teachers College, 1930 . 
Books (con) Sisson, Edward 0. , Educating for Freedom, New York, The

Terry, P.

Thirty-third Yearbook, National Society for the Study of Education, Bloomingt on, Illinois, Fvblic school Publishing Company, 1934.

Thomas-Tindal, E. V., and lieyers, J. D., Junior High School Iife, New York, The Macmillan Company, 1924.

Twenty-fifth Yearbook, National Society for the Study of Education, Bloomington, Illinois, Public School Fublishing Company, 1926.

Vandenburg, Jose ph K., The Junior High School Idea, New York, Henry Holt and Company, IO22.

\section{Periodicals}

Archer, C. P., "School Government as an Educational Agency," The School Review, June, 1923

Beatty, Williard w., "For the Social Education of Children," Progressive Education, February, 1933. Bowden, A. 0., "Student Self Governme nt," "The School Review
July, 19is.

Briggs, Thomas H., "Extra Curricular Activities in Junior Figh Schools," Educational Administration and Supervision, January, 1922.

Chewning, John C., "Student Self Government," National Education Association, Addresses end Proceedings, Vol. 63, 1925.

Dustin, C. R., "An Investigation of the Scope, Working Practices and limitations of Pupil Participation in Government in Secondary Schools," The School Review, June, 1926.

Foley, R. H., "Pupil Participation," Junior and Senior Clearing House, September, 1933. 
Fretwell, E. K., "Education for Leadership," Teachers College Record, September, 1919.

Froula, V. K., "A Phase of Student Guidance," Bulletin of the Department of Secondary School Principals, February, 1933.

Hampshire, In. A., "Training for Democracy," School Executives Ilagazine, August, 1934.

Harbeson, John W., "The Nature and Functions of the Forvard Looking Secondary School," The Education Digest, liay, 1936.

Hartshorn, C. B., "A Study of Pupil Participation in Iowa High School Government," School and Society, September, 1933.

Jackson, N. A., "Pupil Government in Secondary Schools," Education, December, 1921.

Jeter, Everett V., "What I No Student Council?" Junior and Senior Clearing House, October, 1934 .

Juergensomeyer, I. K., "Students Run This School," School Executives Magazine, June, 1935.

Kelley, Earl c., "Utilizing Student Power", Journal of the National Education Association, October, 1936.

Lanks, H. C., "Student Participation in Government," School and Society, July-December, 1936.

Lawson, F. Melvyn and líprphy, Iralcolm P., "A Class in Student Government," California Journal of Secondary Education, hay, 1937.

Lyman, R. L., "The Ben Blewett Junior High School of St. Louis," The School Review, Jamuary-February, 1920.

Mclvulty, Louise, and Bolt on, EuriBelle, "Student Government In the Junior and Senior High School," The High School Quarterly, April, 1936.

Messer, Larie Rita, "Training for Civic Leadership," Education Digest, April, 1937.

Parmenter, Ethel M., "Student Government, A Prpject Method," The School Review, February, 1935. 


\section{Periodicals (con)}

Pickell, Frank G., "Training for Citizenship through Practice," The School Review, September, 1920.

Pound, Olivia, "Need of a Constructive Social Program for the High School," The School Review, March, 1918.

Reavis, Villiam C., and Van Dyke, George C., "Non-Athletic Extra Curricular Activities," Government Bulletin, No. 17, Part 26, 1932.

Rhemus, Pal, "Philosophizing Enroute," Education Digest, September, 1937.

Ringsdahl, N. Robert, "High School Councils," The School Review, May, 1928.

Roberts, Alexander, C., "An Experiment in Socialization," The School Review, January, 1918.

Ryan, H. H., "The Government of the School," Seventh Yearbook, National Association of Secondary School Princ1peis, 1923.

Sachell, J. Kenneth, "Student Participation in School Administration," The School Review, December, 1922.

Saunders, W. R., "A Student Council in A Secondary School," Educrtion Digest, May, 1936.

Sheldon, James A., "Pupil Participation in School Control in High Schools of Iowa," The School Review, March, 1935.

Sleezer, Nargaret, "Student Citizenship at the Senn High School," The School Review, September, 1924.

Smith, R. R., "Three Experiments in Pupil Self-Government," Education, December, 1916.

Thomason, A. L., "Pupil Government of Champaign Junior High School," The Clearing House, December, 1936.

Tinsley, Samuel B., "Guldance in the Louisville High School," The High School Quarterly, July, 1936.

Voelker, E, W., "The Organization and Function of Pupll Opinion in High School Control," "The School Review, November, 1926.

Vredevoogd, L. E., "Providing Means for Student Participation through the Curriculum," Bulletin of the Department of Secondary School Principals, Karch, 1938. 
Periodicals (con)

Whittaker, M. I., "Realities in Instruction in Citizenship," The Social Studies, April, 1934.

Wilbur, Rày Lyman, "A Guest Editorial," Student Life, March, 1938.

Williams, Norman, "The Opportunity of Civic Classes to Promote Student Government," The Social Studies, October, 1937.

Williams, Norman, "Junior Democracy in the Nation's Schools," Education, March, 1938.

Wray, Robert P., "Point System of Awards for School Activities," The Junior and Senior Clearing House, March, 1935.

Carrother, G. E., "The Co-operative Study of Secondary School Standards," School and Society, May, 1937. .

\section{Unpublished Material}

Records of the Louisville Girls'. High School Student Council, kept by Miss Jane Wanless, Halleck Hall.

Poole, C. F., "Student Participation in School Government," Thesis, Teachers College, Greely, Colorado, 1928. 
EDUCATION

Elementary

Secondary

College

Græduate Work
- Public Schools of Loulsvilie, Kentucky.

- Louisville Girls High School, Louisvilie, Kentucky.

- University of Louisvilie, B. A., 1929.

- University of Louisville, M. A., 1939.

Summer work at the University of Loulsville.

TEAGH ING RECORD

Elementary schools in Loulsville, Kentucky:

George Rogers Clark

George Washington

Camp Taylor Afternoon School for Soldiers, (1919-1920)

George $\mathrm{H}$. Tingley

Junior High Schools in Louisville, Ken tucky:

Louisville Junior High. Teacher of:

Social Studies. 